University of Rhode Island

DigitalCommons@URI

Open Access Master's Theses

1981

\title{
Go Anywhere We Damn Well Please The American Naval \\ Presence in the Mediterranean
}

Maureen Melvin Sowa

University of Rhode Island

Follow this and additional works at: https://digitalcommons.uri.edu/theses

\section{Recommended Citation}

Sowa, Maureen Melvin, "Go Anywhere We Damn Well Please The American Naval Presence in the Mediterranean" (1981). Open Access Master's Theses. Paper 1815.

https://digitalcommons.uri.edu/theses/1815

This Thesis is brought to you for free and open access by DigitalCommons@URI. It has been accepted for inclusion in Open Access Master's Theses by an authorized administrator of DigitalCommons@URI. For more information, please contact digitalcommons-group@uri.edu. 
GO ANYWHERE WE DAMN WELL PLEASE

THE AMERICAN NAVAL PRESENCE

IN THE NEDITERRGNEAN

1946

BY

MAUREET WELVIN SONA

A THESIS SUBMITTED IN PARTIAI FULPILINENT OF WHE REQUREWER FOR TES DEGRE OP

NGER OE ARTE

$I N$

HISTOR:

UIVRATTY OF RHOD, TBWAD

83 


\section{ABSTRACT}

Freedom of the seas is one of the oldest policies ... of the United States. We demand the right to go anywhere anytime. It is nobody's damn business where we go. We shall go anywhere we please....

$$
\begin{gathered}
\text { Admiral Bull Halsey } \\
\text { August } 29,1946 \\
\text { Naples, Italy }
\end{gathered}
$$

The presence of the United States Sixth Fleet in the Mediterranean is an accepted fact of diplomatic life. The ships and planes of the U. S. Navy represent American interests in such diverse countries as Egypt, Israel, Greece, and Turkey. That this force is of relatively recent origin is often obscured by the unquestioning acceptance of a global mission for the United States Navy. Such was not always the case.

In the immediate post-World War Two period, the United States possessed the strongest maritime force in the world; nevertheless, despite its superiority, the United States Navy was, at this time, fighting for its very existence. The development and utilization of the atomic bomb had apparently destroyed the premise upon which rested the rationale for a strong Navy. The intense and bitter unification controversy further undermined naval support. By 1946, the U. S. Navy was viewed by many as an expensive, 
obsolete "military dinosaur."

The actual commitment to create a large, standing naval force in the Mediterranean grew out of the conjunction of a complex set of perceptions of and responses to Soviet activities in the Eastern Mediterranean and a need by naval leaders to acquire a viable mission for the Navy in an era when traditional military strategy and foreign policy were distorted by the atomic bomb. The upheaval caused by World War Two had created a serious political vacuum throughout the world. At the war's end, the United States perceived an existing power void in the Mediterranean; saw this vacuum as a threat to her national interests, and, accordingly, took steps to meet the challenge.

This thesis explores and examines those political and military actions taken by the United States to secure its hegemony in the Mediterranean area out of which resulted the establishment of the U. S. Sixth Fleet, both symbol and substance of American power in that area. Utilizing contemporary sources, it delineates the impact of such a naval commitment on United States-Soviet relations in the immediate postwar period and exposes the broader implications of such naval activity for United States global foreign policy.

This thesis further argues that the creation of the U. S. Sixth Fleet resulted from the overlap and interplay of: (I) the g-obal naval policy envisioned by the secretary 
of the Navy, James V. Forrestal, which required a positive demonstration of the efficacy of a naval response to increasing Soviet activity in Europe; (2) the quest for a rationale upon which to build a postwar Navy consistent with the realities of the Atomic Age which led many prominent naval partisans to seek a theater in which to prove the Navy's worth. The decision to dispatch the USS Missouri in April 1946 and the USS Franklin D. Roosevelt in September of the same year provided just such a stage, and was the pivotal point at which these two motivations--advancing the interests of the United States and those. of the U. S. Navy--intersected and overlapped. 
TABIE OF CONTENTS

ABSTRACT. . . . . . . . . . . . . . . $i i$

INTRODUCTION. . . . . . . . . . . . . . . I

Chapter

I. AMERICAN NAVAL PRESENCE IN THE

MEDITERRANEAN PRIOR TO 1946. . . . . . . . 6

II. THE UNIFICATION BATTLE. . . . . . . . . I7

III. JAMES FORRESTAL: ARCHITECT OF A MODERN NAVY. . . . . . . . . . . . . 29

IV. THE TURKISH CRISIS OF 1946: THE SOVIET UNION AND THE TURKISH STRAITS. . . . . . 43

V. THE UNITED STATES NAVY IN THE MEDITERRANEAN, 1946............. . . 53

The Cruise of the USS Missouri to Turkey and Its Impact

The Cruise of the USS Missouri to Greece and Its Impact

VI. THE BUILD UP OF UNITED STATES NAVAL FORCES IN THE MEDITERRANEAN. . . . . . . . . 73

VII. THE ESTABLISHMENT OF THE UNITED STATES SIXTH FLEET. . . . . . . . . . . . . . . 83 VIII. CONCLUSION. . . . . . . . . . 88 APPENDIX A. . . . . . . . . . . . . . . 91 APPENDIX B. . . . . . . . . . . . . . . 92 BIBLIOGRA PHY. . . . . . . . . . . . . . 93 


\section{INTRODUCTION}

The Mediterranean is the Helen among oceans. Iike her it was desired by all who saw it fought over not for ten but for two thousand years, and captured by the boldest. I

"Mediterranean" is etymologically derived from the Latin, meaning "in the middle of the land." This is precisely where the Mediterranean Iies, strategically situated with Europe to the North, Asia to the East, and Africa to the South. Small in comparison with the world's two great oceans, the Mediterranean Sea is, nevertheless, formidable. The Sea measures 2,200 miles from the Straits of Gibraltar to Iskendrun, Turkey; it has a width of 600 miles, is over 16,000 feet deep in several locations, and occupies an area of over 169,000 square miles. 2 For example, an American aircraft carrier, traveling at twenty-five knots (nautical miles per hour), would take three days and nine hours to reach Istanbul, Turkey from Gibraltar. A Soviet Kresta II class guided missile cruiser coming from the Black sea has a trip of 814 miles to Port Said, Egypt, the entrance to the Suez Canal. The nation which controls the three main

${ }^{1}$ Jesse W. Lewis, Jr., The Strategic Balance in the Mediterranean (Washington: American Enterprise Institute for Public Research, 1976), p. I ranean Sea."

World Book Encyclopedia, 1980 ed., s.v. "Mediter- 
points of passage--the Straits of Gibraltar at the western end of the Sea, the Suez Canal connecting the Mediterranean with the Red Sea and eventually with the Indian ocean, and the Turkish Straits ${ }^{3}$, the pathway between the Black Sea and the Mediterranean--effectively controls the entire Sea.

The Mediterranean can be viewed as the crucible of world politics. Over the centuries, great powers have circled each other in the Mediterranean--each attempting to enhance their relative position while implicitly challenging the other to seize the advantage. Some of the world's great battles have raged there, battles which decided the direction of world history. However, the Mediterranean is more than an arena for super-power confrontations. It is the geographical, commercial, religious, social, and most importantly, strategic junction of three continents. The challenges, opportunities, and risks concommitant with a mixture of conflicting interests and options, invariably create a political vacuum. Following the end of World War Two, the United States perceived an

3 The Turkish Straits consist of the Dardanelles, the Sea of Marmara, and the Bosphorus. The Dardanelles, leading from the Aegean Sea into the Sea of Marmara, are about 35 nautical miles long and about 2 nautical miles wide. The Sea of Marmara, connecting the Aegean in the West through the Dardanelies and the Black Sea in the East through the Bosphorus, is about 110 nautical miles long and 40 nautical miles wide. The Bosphorus is about 17 nautical miles long and from 800 yards to 1 I/2 nautical miles wide. These dimension permit easy defense of the waterway. Control 
existing power void in the Mediterranean; saw this void as both a threat to maintenance of her national interests and an opportunity for the expansion of American global hegemony. Accordingly, the United States took positive steps to meet the challenge.

Officially established July 1, 1946, the presence of the United States Sixth Fleet is, today, an accepted fact of diplomatic life. The Fleet exists as both symbol and substance of American military presence in the Mediterranean basin. Simply stated, its mission is to act in support of United States foreign policy and interests in the Mediterranean area; collaterally, the U. S. Sixth Fleet stands prepared to support the North Atlantic Treaty Organization as a NATO Strike Force. ${ }^{4}$ Comprised of between forty and fifty ships, the Sixth Fleet projects a potent political and psychological image. The carrier battlegroup (approximately fourteen ships in support of an aircraft carrier) is regarded as the striking edge of this force. Additionally, part of the Sixth Fleet which is not readily seen but nevertheless acknowledged as present is a substantial nuclear submarine force. The fact that these forces can

Turkish Straits is a simple military matter. (See Appendix A for a map of the area.)

${ }^{4}$ In 1952, Greece and Turkey were accepted as full members in NATO. This inclusion broadened the mission: of the Sixth Fleet due to its subsequent assignment as NATO strike Force. The existence of force-in-being gave NATO 
can deliver either conventional or nuclear weapons on any target within a thousand miles circumference of the Fleet's position cannot be easily ignored.

Since its inception, the Sixth Fleet has been involved in five major conflicts--the Suez Crisis of 1956, the Lebanese Civil War of 1958, the 1967 Arab-Israeli War, the 1970 Jordanian Crisis, and the 1973 Arab-Israeli War. Under the broad mission of protecting American interests, the Sixth Fleet evacuated Americans from Israel and Egypt in 1967, landed Marines in Lebanon in 1958, provided a dramatic show of force during the Jordanian crisis, and completed the communications and logistics link between the United States and Israel during both the 1967 and 1973 wars. Although fleet components were utilized directly in several conflicts, in each instance, their most important application was diplomatic--a clear signal to America's allies that U. S. support was dependable and to the Soviet Union that the United States considered its interests in a specific crisis to be sufficient enough to commit the Sixth Fleet.

American interest in the Mediterranean today is obvious. America requires Middle East oil, and the Mediterranean is the vital link to that oil. However, of greater importance in the Mediterranean than the access to

its deterrent value. 
oil is the need to preserve and enhance the credibility of American power and to ensure that the traditional foreign policy concerns of the United States be safeguarded. Since 1899, when John Hay first publically enunciated the "Open Door, "American foreign policy has consistently been guided by a dynamic expansionism. Although the "Open Door Notes" had been initially directed at Great Power involvement in China, by 1945 the United States had extended its scope to include the entire world. 5 In the Mediterranean Sea, the "door" needed to remain open to ensure quick, secure access to the Middle Eastern petroleum reserves. The United States viewed Soviet ambitions as inimical to the maintenance of free and easy access to these resources. The commitment of American naval forces to the Mediterranean in the post-World War Two era clearly represented this global application of the Open Door policy. Although the United states had been active in the Mediterranean sea for over a century, the introduction of American vessels on such a large scale mirrored new strategic concerns and unexpected diplomatic pressures.

5 The post.World War one pattern of open-door expansion into the oil rich Middle East was a precursor of the military involvement which was to follow the second World War. For an excellent discussion of the uses of the Open Door in the Mediterranean area, see William A. Williams, The Tragedy of American Diplomacy (New York: Dell Publishing Co., 1972 ed.) Chapter 4, Part II. 


\section{CHAPTER I}

\section{American Naval Presence in the Mediterranean Prior to 1946}

As early as 1801, a young United States dispatched its first naval contingent to the Mediterranean. This battle squadron, comprised of the schooner Enterprise and the frigates Philadelphia, Essex, and President entered Gibraltar harbor on July 5, 1801.6 The mission of this group was multi-purpose: to project American presence into an area which was tightly controlled by the British, to secure pledges of peace and cooperation from various North African states, to assist American diplomatic personnel, and to protect the rapidly increasing American commercial interests in the area. By 1803, the U. S. Naval forces in the Mediterranean had more than doubled in size. Clearly this fledgling Republic perceived that its prestige and honor, in addition to the viability of its nascent commercial ventures, necessitated this naval presence, despite the tremendous monetary costs and the critical over-extension of meager American maritime assets.

The Navy proved itself to be increasingly effective

${ }^{6}$ Jesse W. Lewis, Jr., The Strategic Balance in the Mediterranean, p. 12 
in protecting American trade in the Mediterranean. 7 Accordingly, Jefferson permitted the Mediterranean squadron to remain on station until 1807. By 1807 however, economic difficulties within the United States necessitated closure of the shore support base at Syracuse, Sicily and the disestablishment of the Mediterranean squadron. American naval vessels, nevertheless, continued to cruise the Mediterranean; however, they sailed as single units and depended upon British shore establishments for logistical support.

American reliance on British shore facilities came to an abrupt end with the outbreak of the War of 1812 . Great Britain barred American commerce from the Mediterranean, and the small, over-extended American Navy was in no position to challenge the world's greatest maritime power. Congress, however, supplemented the United States Navy with hundreds of newly commissioned privateers. Their mission--to steam independently and prey upon British shipping whenever and wherever possible--was eminently successful. 8 Athough the British Navy retained supremacy in the Mediterranean before and after the War of 1812, the courage,

7 Leonard F. Guttridge and Jay D. Smith, The Commodores (New York: Harper \& Row, 1969) pp. 24-36

8 The Essex and the privateers who accompanied her virtually wiped British whaling interests from the Pacific Ocean: thus, making the phenomenal growth of the New England whaling industry both easy and profitable. See Irving Werstein's The Cruise of the Essex (Philadelphia: MacRae Smith, 1969) 
seamanship, and skill of their American counterparts earned these American sailors grudging respect and admiration from their British adversaries. The first links of future AngloAmerican naval partnership were forged during these early decades of the nineteenth century.

The Treaty of Ghent, ending the War of 1812, had hardly been signed when the U. S. Congress officially declared war on Algiers. American naval actions during this period have been immortalized in the national mythology. Stephen Decatur's exploits, the "shores of Tripoli,". and the eventual defeat of Algiers all fuelled a sense of spirited nationalism within the United States. However, little mention is made of the fact that the power of the Dey of Algiers actually was broken by a joint Anglo-American-Dutch effort and not by the daring activities of Decatur and the United States Marines.

Following the successful conclusion of the Barbary War, the Navy resumed business as usual. Still forced to depend upon the British for logistics and repairs, the United States Navy also found itself protecting a burgeoning national commerce and a greatly expanded fishing and whaling industry. A single casual cruiser would no longer suffice. Therefore, the U. S. Navy established permanent cruising stations in most of the world's waters. 9 United

9 The United States Navy had small squadrons cruising most of the world's waters. In a day when the Indian Ocean 
States warships assigned to the Mediterranean made the circuit of the Sea's choicest ports--Syracuse, Valletta, Marseille, Malaga, and Mynorca. Generally, the Mediterranean was considered the early Navy's most pleasant assignment--beautiful women, delightful climate, magnificent scenery, and just enough excitment to make life interesting. 10 over the next three-quarters of a century, American naval vessels in the Mediterranean would steam from port to port acting as visible representatives of the United States in a sea still controlled by British power.

The period from 1865 to 1890 was a time of considerable American naval stagnation. The easy cooperation with and dependence upon British naval power in the Mediterranean and in the Far East permitted the American Navy to act as passive representatives in those areas. The American Navy was essentially a third-rate power. Particularly interesting during this period was the antagonistic rhetoric within the United States (especially in Congress) towards Great Britain; yet despite these anti-Anglo sentiments, the American Navy's reliance upon British infrastructure in the Mediterranean actually increased.

occupies such a prominent position in the minds of naval strategist (and is present in the press to the American people as a "new" concern of the U. S.), it is hard to believe that the U. S. Navy possessed an Indian Ocean squadron as early as the third decade of the nineteenth century. ${ }^{10}$ Ieonard Guttridge and Jay Smith, The Commodores, pp. 
Maintenance of the European squadron in the Mediterranean was openly attacked by the Congressional committees of this period. To some congressmen, supporting a large, standing navy for protection of commerce seemed an expensive luxury; this burden of maintaining ships in the Mediterranean (where American shipping was rarely if ever harrassed) seemed absolutely unjustified. While some congressional leaders continued to argue against the forward deployment of naval forces in the Mediterranean, the Navy quietly but staunchly continued to endorse it. ${ }^{11}$ By 1880 , the Mediterranean assignment had gained the reputation as easy, comfortable duty; attendance at frequent balls, parties and other social affairs appeared to be the raison d'etre for the Mediterranean Squadron. Even the pro-service Army and Navy Journal admitted in 1880 thet the European squadron was "as large as, or perhaps larger than, any real necessity demands. "12

Thus, by the late $1880^{\prime}$ 's the continued maintenance of a squadron in the Mediterranean was due largely to the inertia of tradition. No pressing military need demanded a strong American Navy in Mediterranean waters; and Congress was complacent, allowing in many cases, a single, over-aged vessel to represent American interests. Congressional

$$
\begin{aligned}
& { }^{11} \text { Ibid. } \\
& { }^{12} \text { Ibid. }
\end{aligned}
$$


disinterest in a Mediterranean naval presence was visible in the deteriorating conditions of the ships assigned to the area--speeds of over four and one-half knots were prohibited lest the ship disintegrate. ${ }^{13}$ European officers considered the American ships floating maritime museums, fit only to occupy a berth.

The dynamic expansion of the United States during the 1890's necessitated the development of a vigorous, modern navy. Accordingly, in 1888, a major program of naval construction was undertaken to convert the rot-ridden, sail-driven American Navy to a fast, modern, steam-driven maritime force. By late 1890, the first American steam squadron appeared in European waters. ${ }^{14}$ Although an extensive and highly successful deployment, these maneuvers were not repeated for another thirteen years, another clear example of the lack of American interest in the Mediterranean Sea. Between 1890 and 1903, any U. S. warships which did visit Mediterranean ports were usually alone and invariably on their way to or from the Far East.

Naval endeavors after 1898 were characterized by

13William J. Hourihan, "Best Ambassador: Rear Admiral Cotton and the Cruise of the European Squadron, 1903," Naval War College Review (June-July 1979): 63

$$
\begin{aligned}
& 14 \text { Ibid., p. } 64 \\
& 15_{\text {Ibid., }} \text { p. } 65
\end{aligned}
$$


set and drift, reaction and counterreaction. The Navy Department's Bureau of Navigation possessed no coherent fleet policy. The Navy's first class warships were dispersed haphazardly around the globe, effectively dissipating any concerted United States naval presence. The appearance of a squadron centered around a capital ship-ofthe-line is certainly more effective than the presence of a single casual cruiser.

The presidency of Theodore Roosevelt, an ardent disciple of Alfred Thayer Mahan, brought clarity and direction to American naval strategy. Roosevelt and Mahan both viewed the Navy as an effective instrument of foreign policy-flexible, mobile, and responsive. An astute politician, Roosevelt realized that single units cruising alone did not project the power necessary to be coercive. ${ }^{16}$ The "gunboat diplomacy" of the era was born out of the realization that it is, the perception of force-in-being which is diplomatically important not necessarily the scope of the area patrolled.

In April 1904, the Sultanate of Turkey refused to negotiate with state Department officials regarding satisfactory protection of an American missionary school in Turkey. The combined forces of the United States Navy

16 Roosevelt clearly illustrated his perceptions of the uses of naval power when he dispatched the Great White Fleet on its around-the-world cruise in 1907. 
present in the Mediterranean at that time were dispatched to Piraeus, port of Athens (Iocated within one day's steaming time of the Dardanelles), to impress the Sultan with the presence of American power. Throughout the course of the delicate and involved diplomatic negotiations regarding the protection of American missionaries in Turkey, the pivotal element of suasion underlying the eventual solution was the presence, "in force," of the U. S. Navy in waters adjacent to the Turkish littoral. 17 However, with this one exception, the cruises of greatest diplomatic importance in Europe centered upon English, German, and French ports which bordered, not the Mediterranean, but the Atlantic. ${ }^{18}$

In August 1914, the outbreak of the First World War altered the nature of American naval presence in the Mediterranean waters. The United States, non-belligerent, pulled American warships out of the dangerous areas to prevent possible incidents. Only after April 1917, when the United States entered the war, did the U. S. Navy reappear in the Mediterranean, and then, only in support of land actions.

During this period between the world wars, naval forces in the Mediterranean remained on the periphery of

17William J. Hourihan, "Marlinspike Diplomacy: The Navy in the Mediterranean, 1904, "United States Naval Insttitute Proceedings (January 1979): 43

18 Idem, "Best Ambassador: Rear Admiral Cotton and the Cruise of the European Squadron, 1903," p. 68 
American national interests. Specific actions taken by naval commanders such as Rear Admiral Mark Bristol and Rear Admiral H. Kent Hewitt in support of American interests in the Eastern Mediterranean were competent, astute, and productive. 19 However, the United States government perceived that America's real naval interests lay elsewhere, specifically in the Far East and the Caribbean. It was primarily to these areas that the energy and attention of the United States Navy were directed.

Throughout the Second World War, naval strategists persisted in viewing the Mediterranean as secondary to the more important mission of defeating the Japanese. In the European theater, the United States was reluctant to become involved deeply in the Mediterranean, viewing an assault on Germany from the North as more urgent. After much pressure from Churchill, who desperately wanted assistance in protecting British interests in the Sea (particularly the approaches to the Suez Canal), the United States Navy entered the Mediterranean. Generally, however these units were limited to support of amphibious landings. American leaders considered this incursion into the Mediterranean as one of many approaches for the campaign against Germany.

${ }^{19}$ Dr. Henry P. Beers, "U. S. Naval Detachment in Turkish Waters, 1919-1924", Administrative Reference Service Report No. 2 (Washington: Office of Naval Records Administration, Administrative Office, Naval Department, June 1943). 
The United States was content to leave control of the Mediterranean sea lanes to the British to whom the protection of the sea link to India was an imperative national interest. By the end of World War Two, the power and prestige of the United States was unsurpassed, especially the large and modern U. S. Navy. The Mediterranean Sea, once a British lake and the lifeline of the British Empire, was now ringed by war-devastated countries--Britain was prastrate; France, enfeebled; Italy, starving; Greece, ripped by civil war; and Turkey, frightened. The Soviet Union had acquired considerable territory in Eastern Europe and was making threatening overtures to Turkey and Greece.

Secretary of the Navy James V. Forrestal perceived it as vital to the national interests of the United States that it assume a position of hegemony in the Mediterranean. Taking advantage of a unique "humanitarian" political opportunity., Forrestal, with the agreement of secretary of State James Byrnes, dispatched the USS Missouri in March 1946 to return the remains of the Turkish Ambassador to Istanbul. This single goodwill visit was the genesis of the Sixth Fleet.

The establishment of the United States Sixth Fleet was the result of a complex marriage of the efforts of an enigmatic and energetic Secretary of the Navy to implement his global military strategy and the needs of naval leaders to find a viable postwar mission for a fleet which, in the 
atomic age, some characterized as a "military dinosaur." The Navy, in 1945-1946, was threatened by many forces-the move to rationalize the armed forces by consolidation, the nullification of traditional strategic precepts by the atomic bomb, and the headlong rush toward demobilization and demilitarization. The Eastern Mediterranean crisis. of 1946 and 1947 posed the possibility of salvation, and Navy officials hastened to seize the opportunity. 
The Unification Battle

World War Two had been waged under the aegis of joint and unified command structures, but the American military establishment itself was not, at that time, in the hands of a consolidated defense department. Planning for the postwar military configuration was, therefore, divisive and parochial. Each service was obsessed with ensuring that demobilization and unification would be accomplished with minimum detriment and maximum benefit to that particular service. 20

The manner of demobilization was an important consideration for the services however, the unification of the American military establishment was the primary object of postwar planning. Intense and acrimonious debates surrounded the unification controversy as each service proposed unification plans designed to guarantee its predominance.

These temsions had their roots in the prewar years,

20 Vincent Davis, Postwar Defense Policy and the U. S. Navy, 1943-1946 (Chapel Hill: The University of North Carolina Press, 1962), preface. Davis provides a thoroughly researched account of the domestic aspects of the unification controversy. 
particularly during the Billy Mitchell Hearings on the formation of a separate Air Corps. Mitchell had argued that all naval air forces should be turned over to a separate Air Corps. Of much greater concern to the survival of a modern Navy was Mitchell's contention that all surface forces--especially naval forces--were obsolete. As Mitchell's advocates pushed for Air Corps autonomy following World War One, the recurring notion of unification of the armed forces in order to achieve governmental efficiency and to reduce waste and duplication surfaced with surprising strength. With particular acumen, supporters of Billy Mitchell's thesis pressed Congress for the establishment of a separate Air Corps with a centralized organizational structure to be superimposed over all three services--Army, Navy, Air Force. Thus, with the advent of World War Two, Air Force advocates were able to place themselves firmly on the side of those in Congress who supported unification. The Army Air Corps was able to garner some important support for its unification battle which would begin in earnest once the war had been won.

The internecine conflict regarding which service would control which theater of operations repeatedly erupted during the war. The continued deterioration of interservice relations during World War Two was particularly evident in the jurisdictional dispute in the Pacific theater. 
The Joint Chiefs of Staff, themselves a creation of war, drew a dividing line across the Pacific Ocean, assigning the Southern theater to General Douglas MacArthur and placing the Northern under the direction of Admiral Chester Nimitz. ${ }^{21}$ This agreement was accepted, albeit grudgingly, by the Navy, but when the Army pressed for over-all control of the invasion of the Japanese home islands, the Navy balked. Acrimonious debate raged within the services over who would lead the force. However, the development and employment of the atomic bomb relieved the Joint Chiefs of Staff from having to make the decision in favor of either service.

Furthermore, the necessary and continous closeworking relationship between Army Chief of Staff General George Marshall and Chief of Naval Operations Fleet Admiral Ernest King--both men shared a deep personal animosity-made the uneasy truce between the departments virtually impossible to maintain. This clash of wills and its effect upon service operations was clearly illustrated in the bitter debate over which service--the Army or the Navy-would have cognizance over the antisubmarine warfare operations in sea lanes within reach of land-based airplanes. The wrangling continued to intensify (with neither service doing the job adequately) while King, insistent that

\section{${ }^{21}$ Vincent Davis, Postwar Defense Policy and the} U. S. Navy, 1943-1946, p. 49. 
submarine warfare was the Navy's job, stood his ground until Marshall capitulated. 22

The unification controversy flared publically for a brief period in April 1944, with the commencement of the Woodrum Committee hearings. These hearings focused on the question of reorganizing the postwar military services into a single department which would include a separate Air Force. A strong Navy rebuttal, orchestrated by Undersecretary of the Navy Forrestal, convinced the Woodrum Committee to delay the unification decision. ${ }^{23}$ Consequently, the Committee adjourned without a decision, simply agreeing to put off the hearings indefinitely.

The Navy Department, satisfied with the successes of the Woodrum Committee, allowed the unification question to sink into bureaucratic limbo. For a year, leading naval officers did nothing to forestall another Army offensive on unification. However, by the spring of 1945, two separate occurrences rekindled the controversy: the report of the Richardson Committee on Unification ${ }^{24}$ and the

${ }^{22}$ Marshall did not give in to King's demand that the Navy have cognizance over all antisubmarine warfare until a German submarine approached to within three miles of the entrance of the Chesapeake Bay undetected.

23 Forrestal appeared before the Wood rum Committee instead of Secretary of the Navy Knox because Knox had been incapacitated by a heart attack. Knox died during the Committee Hearings and Forrestal became Acting Secretary. 24 Records of the Hearings before the Senate Committee 
intensification of the Army Air Corps' public relations campaign which sought to glorify all its heroes, past and present, and attempted to make it appear as if the Air Force had won World War II singlehandedly.25

The importance of the Richardson Committee was underestimated by the Navy. Fleet Admiral King, Chief of Naval Operations, made several tactical errors. Although King appointed Admiral J. O. Richardson, a known opponent of unification, no one had troubled to ascertain the views of Rear Admiral M. S. Schoeffel, an inconspicuous career naval officer, the other naval appointee. Furthermore, the Navy Department had agreed to accept an "alternate" member of the committee, with the understanding that the "alternate" would take no part in the proceedings unless one of the primary members were incapacitated for a lenghty period.

This agreement that the "alternate" member of the Richardson Committee, Colonel F. Trubee Davison, would exercise no initiative soon evaporated. General William Tompkins, the senior War Department member, was hospitalized with pneumonia while the other members of the committee, including Colonel Davison, toured the Pacific. General

on Military Affairs on S. 84 and S. 1482, 79th Congress, 2nd Session (Washington: GPO, 1945) contained an abridgment of the Richardson Committee Report to the Joint Chiefs of Staff.

${ }^{25}$ Vincent Davis, Postwar Defense Policy and the 
Tompkins quickly returned to duty, but, as a result of his brief absence, found his duties shared by Colonel Davison. The net result of this maneuver was that both Davison and Tompkins helped to draft and sign the final document.

The majority report of the Richardson Committee was submitted on April 11, 1945. Its wording stung the Navy opponents of unification:

The Special Committee, excepting the senior naval member, is unanimously in favor of a single department system of organization of the Armed Forces of the United States....The Special Committee believes that enabling legislation for the creation of a single department should be enacted without delay...not later than six months after the end of the war. 26

The innocuous language of the report attempted to assuage Navy fears that unification was tantamount to emasculation. However, the intentionally vague and ambiguous assurances only served to intensify the Navy's convictions that the end result of a single department system for national defense would be a weak, third-rate navy. The Richardson Report struck at what Forrestal and the young admirals who had won their stars in the Pacific considered the soul of the modern navy--the Naval Air Forces and their carriers. Admiral John $\mathrm{S}$. McCain summed up Navy suspicions in a letter to Secretary Forrestal on April 28, 1945:

No matter how fair the words, or beguiling the

U. S. Navy, 1943-1946, p. 148

${ }^{26}$ Lawrence Legere, Jr., "Unification of the Armed 
phraseology, and regardless of intent, a unified command, a single service or department of national defense, will of necessity be an instrument for extra-constitutional and an interested division of funds prior to submission to the disinterested Congress. The Army banks on controlling the individuall who will head this single unit, and historically, they will be correct in that assumption.

There will be little planes as well as big planes that will sink all types amphibious tanks can be built up to that role for public consumption. This will appeal to the grand American delusion that wars can be fought cheaply.

It is beginning to look to me that the war after the war will be more bitter than the actual war. 27

A vigorous Air Force public relations offense against the Navy followed quickly on the heels of the Richardson Report. The first important salvo was a ninety-five page "conclusion" appended to General H. H. ("Hap") Arnold's second wartime report to the Secretary of War. Arnold stated that

We must first recognize that the only certain protection against aggression is the ability to meet and overcome it before the aggressor can strike the first blow. In the past such blows have been waterborne; traditional naval power was our first line of defense. From now on successful a gression must come from the air....Our first line of defense must be the air. 28 Arnold made it readily apparent that he did not include

Forces", (Ph. D. dissertation, Harvard University, 1950) p. 69

27 Robert G. Albion, Makers of Naval Policy, 17981947 (Annapolis: Naval Institute Press, 1980), p. 607. 28 Vincent Davis, Postwar Defense Policy and the U. S. Navy, 1943-1946, p. $\frac{152}{152}$ 
naval air in his definition of "first line of def'ense." He stated that such air power "must be employed from large, fully-equipped, strategically located bases. "29

The Navy began to react publicly to the Richardson Committee Report and to the public relations barrage produced by the Air Force. At the launching of the "supercarrier" USS Franklin D. Roosevelt, Secretary of the Navy James Forrestal asserted that the U. S. Navy deserved the credit for greatly increasing the scope and use of aircraft by applying it to sea power. ${ }^{30}$ Forrestal sought to broaden the strategic and tactical thinking of both Congress and old-line Navy thinkers in his statement before a senate Subcommittee on Appropriations less than a week after the launching of the Roosevelt:

One of the major purposes of the fast carriers interdiction strikes in advance of an invasion is to knock out or pin down Japanese land-based air power around our target. The battles of our carrier-based air power against Japanese land-based air power now comprises one of the great struggles going on in the Pacific. It really points up the question: Can sea air power cope with landbased air power? I think that the answer is in the fact we are coping with it and we have beaten it. 31

The use of the term "sea air power" before a senate

29

Ibid.

30

New York Times, April 30, 1945, p.I

${ }^{31} \mathrm{U} . \mathrm{S}$. Congress, Navy Department Appropriation Bill for 1946, Senate; hearings on H.R. 2907 before the Subcommittee of the Senate Committee on Appropriations, 79th Congress, lst Session (Washington: GPO, 1945), pp. $4-5$. 
committee implied an emerging revitalization of the Navy's image and a new conceptualization of the strategic and tactical value of a modern naval force. Forrestal articulated one of the primary lessons learned by naval officers during World War Two--modern naval warfare was infinitely more complex than such simplistic strategic and tactical concepts as navy-to-navy ratios for battle plans. For more than half a century before the Second World War, the Navy's premier strategic concept was that navies exist for fighting other navies. In his acclaim for naval aviation, Forrestal was categorically stating that the development of naval aviation permitted the rapid and effective deployment of aircraft against land-based forces. Continually, Forrestal emphasized the flexibility of naval aviation:

In my judgement, these great carrier task forces backed up by the surface power of the fleet and by the amphibious striking force of the Marine Corps, constitute the all-purpose weapon. 32

He continued to testify that a postwar navy of sufficient size and flexibility to remain away from homeports for extended periods was mandatory. 33

Before another Senate Subcommittee (Senate Naval Affairs Committee, February 1946), Admiral Forrest P.

32 U. S. Congress, H. of Rep., Composition of the Postwar Navy; hearings before the House Committee on Naval Affairs (available in a single volume entitled Sundry Legislation Affecting the Naval Establishment 1945, Washington: GPO, 1945) p. 1168

33 Sundry Legislation, p. 1169 
Sherman, Deputy Chief of Naval Operations, supported Forrestal's thesis by stating that the U. S. Navy required a fleet capable of operating at speeds from five to fifteen knots, for six thousand miles, for periods of up to 190 days. ${ }^{34}$ These fleet operations would have to be conducted in many areas without the benefit of shore infrastructure support. Sherman envisioned such a navy was required to fulfill future U. S. global mission needs.

In the face of vigorous Army and Air Force offensives, naval leaders continued to project arguments regarding the practical application of sea power in support of foreign policy in an age distorted by the atomic bomb. New fleet organization plans proposed the establishment of fleet task groups, each consisting of four or five battlegroups. 35 Since the battlegroups would be formed around aircraft carriers, the task force would be of sufficient size and flexibility to permit effective diplomatic use of the fleet as a tool of "suasion". 36 This fleet organization, coupled with the expanding concept of "sea air power"--when added to the growing realization that Soviet Russia was a potential

34 U. S. Congress, Senate, Hearings Before the Senate Committee on Naval Affairs, H.R. 4421 (Washington: GPO, 1946) p. 1131

35 Naval Organization Manual, 1946

36

The term "suasion" was coined by Edward N. Luttwak, The Political Uses of Sea Power, The Washington Center of i'oreign Policy Research of Johns Hopkins University School of 
enemy--became the touchstones of the modern Navy.

The chief source of this new Navy would be the exerience of World War Two itself. The United States and the world witnessed a radical departure from the traditional emplo, nent $f$ naval forces. The carrier sea battles which secured the Pacific for the United States emphasized the potency of sea-based aviation and heralded the eclipse of naval tactics which revolved around ship-to-ship combat. The men who had earned their stars in these battles--young, vigorous naval aviators who had captained the carrier forces--were at the helm of this new Navy. Consequently, visionaries continued to see the unlimited potential of sea power, but in a new sense--"sea air power." The problem was, however, to reduce these visions to concrete doctrine instead of tenuous dreams. In this effort old strategic concepts of Mahan were replaced by no single doctrinal statement--the flow of action and policies became the new code. The sense of this new Navy--unclear to some who had made the sea service their lives--was more opaque to the controllers of the defense appropriations, the Congress. The Navy critically needed a spokeman of stature and position who could address these new naval

Advanced International Studies (Studies in International Affairs, No. 23), (Baltimore: The Johns Hopkins University Press, 1974). The term "suasion" refers to the coercive and deterrent value of an effective naval display and its utilization as a tool of siplomacy. 
concepts in a language easily understood by Congressional committees. If this modern Navy lacked.a Mahanesque master of profound statements, it did have a champion and a leader who symbolized the essence of its new soul--James $V$. Forrestal, a political man for a political time. 


\section{CHAPTER III}

James Forrestal:

Architect of a Modern Navy

The American military establishment had been seriously fragmented by the unification controversy. The lack of cooperation between the services was mirrored by a similar abrasive relationship between the civilian heads of service and their military counterparts. Traditionally, military policy decisions had been made and implemented by the military chiefs of the respective services. The various Secretaries represented and exercised only nominal civilian control over policy development and direction. Furthermore, they had little input into broader decisions of national policy. However, the office of the secretary of the Navy during the period 1944 through 1947 was occupied by James V. Forrestal, a man whose influence far outweighed the position he held within government.

Forrestal was sworn in as Secretary of the Navy on May 19, 1944 following the death of Secretary Frank Knox (resulting from a heart attack during the Woodrum Committee Hearings). Knox had been an amiable Secretary of the Navy, allowing events to dictate his actions. Forrestal, on the other hand, was dynamic and aggressive, quick to seize the 
advantage. Forrestal had entered government service as one of Roosevelt's $\$ 10,000$ a year administrative assistants. Several months later Congress created the Office of the Undersecretary of the Navy and Forrestal, a former naval aviator, promptly indicated that he would like to hold the position. On August 6, 1940, he became Undersecretary of the Navy for Industrial Mobilization which he held until becoming Secretary.

While Undersecretary, Forrestal had characteristically broadened the activities of his particular office to include a much larger area of responsibility than actually prescribed. Even before Knox's death, Forrestal had assumed many of the duties and responsibilities of secretary of the Navy. By surrounding himself with highly competent and aggressive assistants, Forrestal involved himself in the postwar planning and the daily operating activities of the Navy Department. When he actually became secretary, the gulf which had once separated civilian from military within the naval establishment was effectively bridged. It is no exaggeration to state that Forrestal, in taking the moribund Navy Department away from the strategic doctrine espoused by the old-line "battleship admirals,", was to have a greater impact on the Navy than any man since Alfred Thayer Mahan. 37

37 Robert Albion, Makers of Naval Policy, p. 604 
As noted, service secretaries normally exercised little influence over policy matters outside the narrow confines of their particular province. Throughout his governmental career, however, Forrestal was inclined to interpret his duties in the broadest possible terms. It was only logical that once assuming the office of Secretary of the Navy he would attempt to expand his duties into international policy matters. He was instrumental in the establishment of the State-War-Navy Coordinating Committee (SWNCC) in November 1944 for the purpose of "formulating recommendations to the Secretary of state on questions having both military and political aspects and of interdepartmental interest. "38 The official recognition of this informal council provided Forrestal and the Navy with a cabinet level platform from which to influence presidential decisions relating to matters of global strategy.

Forrestal feared, above all, the rate at which the country was "going back to bed" and considered such rapid demobilization an invitation for Soviet expansion into the oil-rich Persian Gulf. He conceived that, in the power vacuum created by the collapse of British power, national security demanded the global presence of American military power in general and the United States Navy in particular. 39

38 Robert Albion, Makers of Naval Policy, p. 407 39 Walter Mills, The Forrestal Diaries (New York: The Viking Press, 1951) p.97 
Long before actual overt Soviet moves became evident, Forrestal regarded Russian postwar intentions with growing apprehension. At the root of this wariness was a basic anti-Bolshevik, anti-Soviet attitude predicated upon the Wilsonian ideal that the liberal democratic capitalistic form of government existing within the United States should be the form adopted by all the world's governments. Within this framework, Forrestal perceived any Soviet move as threatening the vital national interests of the United States.

As early as September 1942, Forrestal warned publicly that "never again should this country be permitted to discard its arms and to rely upon protocols of good faith and the general statements of good will." 40 He was convinced that the Russians were determined to push for a much wider sphere of influence than the "Open Door" would permit. He was firmly persuaded that the United States needed a strong military to deter Șoviet expansionism and, if needed, to counter Soviet aggression. He adamently believed that "there would be no peace in the world, no final victory until we demonstrated to the Russians that whenever and wherever we say 'no' we mean business." 41 Forrestal made several initiatives designed to create a postwar global naval presence which would be capable of showing the Soviets "we mean business."

40 Arnold A. Rogow, James Forrestal: A Study in Personality, Politics, and Policy (New York: The MacMillan Co., 1963) p. 124

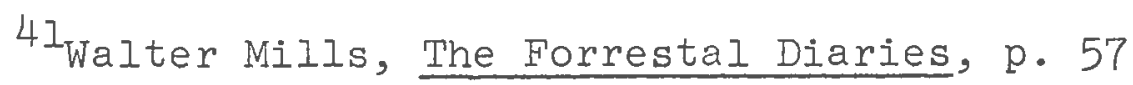


In mid-1945, Vice-Admiral Forrest Sherman, Assistant Chief of Naval Operations for Strategic. Planning, under the direction of Forrestal began work on a new series of war plans. Specifically, the plans involved a "pincher" movement to attack Russia from air bases in Britain and from aircraft carriers in the Mediterranean. ${ }^{42}$ The PINCHER plans, which formed the basis for Joint War Committee Plan $432 / 7^{43}$ postulated that World War Three would erupt with the Soviet Union within three years. The planners assumed that a war with the Soviets would take the pattern of the Second World War, in that it would be global and total, and would start with a Soviet offensive in the Middle East, eventually spreading to Europe. The strategists reasoned that United States petroleum resources would be insufficient for major war after the second year unless supplemented from the Middle East. 44 To dominate the Middle East, the plan estimated that the Soviets would overrun Greece and Turkey, seize control of the Eastern Mediterranean and strike at the Middle East. PINCHER placed the principal theater of

42 Dennis M. Pricolo, "Naval Presence and Cold War Foreign Policy: A Study of the Decision to Station the 6 th Fleet in the Mediterranean, 1945-1953", Trident Report No. 95 (Annapolis: U. S. Naval Academy, 1978), p. 46

43 Memorandum for the Chief of Naval Operations, 7 June 1946, Conference with OP-30 on War Planning, Al6-3(5) War Plans 1946, Operational Archives Branch, Naval History Division.

${ }^{44}$ RADM Cato D. Glover, Memorandum for the Chief of 
concentration and operations in the Eastern Mediterranean. One of the major offensive moves contemplated by the initiators of plan PINCHER was that the American Navy had to be prepared "to seize the Aegean Sea and the Turkish Straits." 45 PINCHER clearly demonstrated the importance of the Mediterranean in a future war and the critical nature of that sea for the American Navy. It was the only area "where Allied naval and air superiority could be brought to bear against the Soviet Union without being exposed to the full force of the Red Army." 46 With the recognition of the potential for conflict with the Soviet Union, the Mediterranean assumed new and unexpected prominence for American naval strategists. In areas contiguous to the sea, the fact that defense of the Mediterranean littoral would be "extremely difficult and costly" without the prepositioning of American naval assets provided substantial and convenient justification for Forrestal's global ambitions. These ambitions required the establishment of a standing Naval force in the Mediterranean.

The relationship of military power to foreign policy continued to preoccupy Forrestal. "It is my strongest personal belief that our diplomatic and military policies

Naval Operations, "Resume of PINCHER Planning," 21 January 1947, Serial 0005p30, Al6-3 War Plans 1947, OP-30 Files, Operational Archives, Naval History Division.

45 Ibid.

46 Dennis N. Pricolo, Trident Study No. 95, p. 72 
must be closely matched," wrote Forrestal in his diary dated July 1946. 47 As always, he followed philosophy with action. In his capacity as Secretary of the Navy, he ordered the inclusion of a course entitled "The Foundations of National Power" in the curriculum of middle-echelon officers at the Naval War College. By autumn 1946, this course was published and made available to all naval personnel via the Naval Correspondence course centers. 48 The importance of training military men in matters of policy was stressed repeatedly in his diary and other papers:

I have one more point to offer: the need for wise, trained men to administer the National Policy. We need men who understand the causes of war and conflict, who understand the interrelation of international policies, trade and finance, and the true significance of military power.... We must find and train such men--outstanding civilians who have served their country under arms and outstanding military men who have studied to understand the civilian aspects of government and international relations. If we don't find and train and enploy such men in the service of the United states, we will lose our shirts... and then what avails the sacrifice of life, blood, and treasure that we have made? 49

Forrestal approached his growing apprehension of the Soviets with typical systematic and scholarly precision. On

\section{Walter Mills, The Forrestal Diaries, p. 72}

48 Ibid., p. 57. That this course was extended to enlisted men as well as officers is a good example of the ability of Forrestal to accomplish what he desired. In what was the least egalitarian of the services, a course offerred to both officer and enlisted was rare.

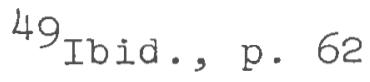


May 26, 1945, he requested $\mathrm{Dr} . \mathrm{E} . \mathrm{F}$. Willett, an aide, to prepare a research paper assessing the aggressive potential of Stalin and the Soviet Union. The result was a forty-five page memorandum, dated January 14, 1946, that concluded:

It has been clearly established that, to the extent that Russian objectives are governed by the principles of Dialectical Materialism and Communist philosophy, that they are directly opposed to the United States and that they are so directly opposed as to make warfare between the two nations seem inevitable....The nature of the paths by which war can be avoided point conclusively to the necessity of our maintaining this nation in a position of such impregnable strength that possible enemies would regard attack on her as suicidal. 50

Another clear indication of the seriousness with which Forrestal regarded the Soviet threat was the fact that upon receiving a copy of the "Iong telegram" written by George Kennan concerning the Soviet Union's future intentions, he immediately had copies made and distributed to all members of the Navy Department. Furthermore, he insisted in a memorandum that all Navy officials be thoroughly conversant with the information contained in Kennan's telegram. 51

Forrestal was obsessed with the notion that a strong postwar navy guaranteed American global hegemony and protected the peace won by World War Two. In his eyes to be less than the strongest nation on earth invited another

50 Vincent Davis, Postwar Defense Policy and the U. S. Navy, 1943-1946, p. 222

${ }^{51}$ Robert Albion, Makers of Naval Policy, pp. 611613 
Munich and by implication, World War Three. However, he faced powerful opposition to his attempts to maintain such a maritime force. Although the preeminence of American power was a shared Administration view, most within the Truman White House saw the strength of United States military presence in an Air Force second to none. Furthermore, the Army had the ear of the President (Truman had been an artillery officer during World war one and held a characteristic disdain for the Navy). The fledgling Air Force, flushed with the power inherent in the ability to deliver the bomb, had acquired important Congressional support in its campaign to receive the lion's share of the postwar defense appropriations. The Air Force attack was particularly acidic. Brigadier General Frank Armstrong, an aviator, expressed the Air Force view quite succinctly:

You gentlemen had better understand that the Army Air Force is tired of being the subordinate outfit, and is no longer going to be a subordinate outfit. It was the predominant force during the war. It is going to be the predominant force during the peace, and you might as well make up your minds whether you like it or not that we do not care whether you like it or not: the Army Air Force is going to run the show. You, the Navy are not going to have anything but a couple of carriers which are ineffective anyway and they will be probably sunk in the first battle.

Now, as for the Marines, you know what Marines are. They are a small, fouled-up army talking Navy lingo. We are going to put the Marines in the regular Army and make efficient soldiers out of them. The Navy is going to end up only supplying the requirements of the Army and Air Force. 52

${ }^{52}$ U. S. Congress, Senate, Armed Services Committee 
Faced with such vitrolic attacks, Forrestal personally went on the offensive. Cautioning naval officers not to speak against unification (President Truman had already signalled approval of the idea), Forrestal insisted they concentrate on the task of building a viable image for the Navy in the atomic world. Forrestal vigorously refuted the idea that the Navy had been made obsolete by the atomic bomb; he stressed that the Navy was moving forward in research and development of carrier-borne atomic weapons. Forrestal and his Navy argued that the atomic bomb, however powerful, was "still a bomb, requiring land-and carrierbased planes to deliver it. "53 Prestigious wartime heroes such as Admirals Chester Nimitz and William "Bull" Halsey publicly discounted the threats that the atomic bomb allegedly posed for the continued existence of the Navy. 54 Speaking at a luncheon in Philadelphia, Admiral Nimitz stated: .

There are some people who claim that the atomic bomb now makes navies obsolete. That has been claimed for every other new weapon, from the smooth-bore gun to the armor-piercing sheil. The submarine and the airplane forced changes in navies and the atomic bomb will

Hearings on Unification, 1947 (Washington: GPO, 1947)pp. 177, 641

53 U. S. Congress, H. of Rep., Composition of the Postwar Navy (Washington: GPO, 1945) pp. 1164-1165 54 New York Times, February 22, 1946, p. 3 
force changes in design and operations of ships.

But while the prophets of naval doom are shouting themselves hoarse, the Navy will be at work to make the changes needed to accomodate American sea power to the new weapon.... The American genius for the exercise of sea power will not be allowed to languish. 55

Forrestal became an extraordinarily effective naval advocate before Congressional committees. A more powerful speaker than former Secretary Knox, Forrestal always entered a Congressional hearing prepared to go on the offensive. Before a House Naval Affairs Committee, he outlined two fundamental reasons why Congress should not cut the Navy's appropriations :

First, the outstanding lesson of the past quarter century is that the means to wage war must be in the hands of those who hate war. The United States must always remain strong. Second, the Navy is a major component of that strength. In each of the past two wars, our enemies have failed to control the seas-- and they were defeated....Attacks upon us or by us must cross over, on, and under the sea.... The key to victory and to freedom will be the control of the seas and the skies above them. 56

Forrestal's appreciation of the "influence of sea power" appeared frequently in his letters, speeches, and diaries. In preparation for a book he never wrote, he delineated his impressions of sea power:

Sea power--what it means. Seventy-one percent of the earth's surface is water... Sea power has still the same meaning it had when the Romans had to get a fleet

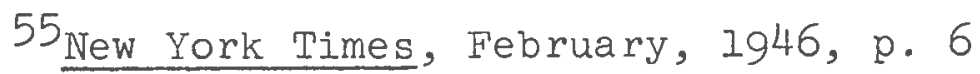

56 Robert G. Albion and Robert H. Connery, Forrestal and the Navy (New York: Columbia University Press, $\frac{1962), p .}{185}$ 
to conquer the Mediterranean. The same as when Britain, one by one, cut off the tentacles of Napoleon's octopus. The same as in 1917, when Anglo-American control of the Atlantic spelled defeat for Germany.... The Army's failure to understand and appreciate sea power--their fundamental attitude that this is a simple matter of transportation. Three dimensions of power; the surface of the seas, the air above it, and the subsurface. 57

Forrestal's concept of sea power as an integral part of American global strategy was never better illustrated than in his advocacy of the reestablishment of American naval forces in the Mediterranean. The basis of his vision of the Navy's mission was the "mystique of visit diplomacy." 58 However, port visits of major warships to countries where political instability was in question (always characterized as "courtesy calls") implied U. S. power-in-being, demonstrated United States concern in that country and threatened the use of force in support of American national interests if necessary. A show of naval strength could provide "a tangible means for the support of policy which air power cannot duplicate." 59 Forrestal realized early that a strong naval presence in the Mediterranean could reach all disputed points (without the necessity of fixed bases), could demon-

57 Ibid. The three dimensions of power described by Forrestal accurately expose his plan for the development of a postwar Navy--the fast attack airplane carrier, the sophisticated carrier-based aviation arm, and the submarine program. Rickover's nuclear "carte blanche" arose out of this need to redefine the Navy's mission in an atomic world. 58 cacy of "visit diplomacy" in the May 1979 U. S. Naval Institute Proceedings.

${ }^{59}$ Albion and Connery, Forrestal and the Navy, p. 186 
strate the power of American striking force, and might possibly encourage the pro-American alignment of other nations. 60

Forrestal's mistrust of the Soviet Union grew almost daily throughout 1945 and 1946. In a speech given April 29, 1946 to the Foreign Policy Association, Forrestal cautioned that Russia was intent upon world conquest:

Russia can be called an enigma but there is no enigma if you plot the long trend of her policy since 1921 ; the use of military power, threats, political infilitration and exploitation of other countries. She is always pushing, receding where rebuffed but like a great tide seeping in elsewhere if there is an opening. 61

As the geopolitical situation in the Eastern Mediterranean grew more critical Forrestal perceived that his fears of Russian intent were accurate--the PINCHER plan predicting war with the Soviet Union within three years was playing out. In an attempt to begin prepositioning naval units in the Mediterranean, he requested Secretary of State Byrnes to consider the feasibility of the Navy preparing plans for a task force in the Mediterranean. ${ }^{62}$ In a memorandum of a SWNCC meeting during which he made his request, Forrestal reported that Byrnes concurred with his idea and

\section{${ }^{60}$ Ibid.}

${ }^{61}$ Forrestal Papers (on deposit in the Mudd Library, Princeton University, Princeton, New Jersey), unpublished Diaries, Vol. 6, p. 1033 p. 763

$$
62 \text { Forrestal Papers, unpublished Diaries, Vol I, }
$$


further suggested that such a task force accompany the USS Missouri which was scheduled to take the remains of Mehmir Ertugun, the late Turkish Ambassador to the United States, home to Istanbul. 
The Turkish Crisis of 1946:

The Soviet Union and the Turkish Straits

The geopolitical situation which led to the establishment of the U. S. Sixth Fleet lay in the traditional struggle of the Soviet Union to acquire control of the Turkish Straits and in the equally traditional efforts of the United States to maintain an "Open Door" worldwide. Prior to the opening of the Yalta Conference on February 2, 1945, State Department officials anticipated that Stalin would raise the issue of control of the Straits and the renegotiation of the Montreux Convention of 1936.63 Soviet jurists had been preparing a case for the special position of the Black Sea states for several years. B. A. Dravov, a prominent Soviet writer, asserted that the Black Sea had a special status as a mare clausum, a "closed sea."64

${ }^{63}$ Stalin had expressed interest in the renegotiation of the Montreux Convention at both Cairo and Teheran. Roosevelt off-handedly said that he thought that it should be changed as it was formulated under the auspices of the League of Nation which was no longer in existence. However, in a private meeting between Churchill and Stalin in October 1944, Churchill informally agreed to the privileged position of the Soviet Union and other Black Sea states vis-a-vis the Turkish Straits.

64 William Butler, The Soviet Union and the Law of
$\frac{\text { the sea (Baltimore: The Johns Hopkins University Press, 1971) }}{\text { p. } 117}$ ) 
The Soviet interpretation of a mare clausum was also represented in a note to the Turkish Government on September 24, 1946:

The Soviet Government desires before all to invite the attention of the Turkish Government to the special situation of the Black Sea as a closed Sea. Such a situation means that the Straits of the Black Sea represent a seaway leading only to the shores of a limited number of powers, namely the shores of the sea powers. Therefore, it is entirely natural that the Soviet Union and the other Black Sea powers are most interested in the regulation of the regime of the Straits of the Black Sea and accordingly their situation in this matter cannot be compared with other powers. 65

The State Department, unsure of exactly what American policy should be, requested that the Joint Chiefs of Staff undertake an analysis of Soviet demands. The study group formed by the Joint Chiefs submitted two separate opinions. A majority opinion (by Lieutenant General Stanley Embrick and Major General Muir Fairchild) stated that the control of the Straits was an historical aspiration of Russia moțivated by economic need. Embrick and Fairchild equated Soviet designs on the Straits to the fact America was seeking postwar bases in Iceland, in the Azores, and thoughout the Pacific. Another member of the study group, Vice-Admiral'Russell Willson, wrote the minority opinion. Willson advocated strong countermoves to Soviet pressures on Turkey and insisted that conceding the Straits would be a new form of appeasement. The Joint Chiefs of Staff, after

65 Fletcher crowe III, "The Soviet Union and the Turkish Straits, 1933-1945" (Ph. D. Dissertation: Florida State University, 1973), p. 197 
reviewing both opinions, forwarded Willson's paper to the State Department. 66

The United States had conceived a carefully constructed response to the Soviet pressures concerning the revision of the Montreux Convention. A memorandum, dated January 5, 1945 and originated by the Navy Department, served as a basis for American policy on the status of the straits:

This Government might not object to minor changes in the Convention, which might at some future date be suggested by the U.S.S.R (the Great Power primarily at interest), or by Great Britain, particularly with respect to the transit and navigation of warships in the straits and their right of sojourn in the Black Sea. Suggested changes of this sort should, of course, $b \in$ carefully considered by the Navy and War Departments.

"Internationalization" of the Straits is not a practical solution at this time because, if that is done, the Suez Canal and the Panama Canal logically should receive the same treatment. Turkey, remembering the capitulations and the "internationalization" which preceded the Niontreux Convention (in itself a practical form of internationalization) would strongly resist such a proposal.67

Stalin continued to press for revision of the straits protocol. He stated that Russian interests must be taken into account in any revision of the Montreux Convention because "it was impossible to accept any longer a situation

66 Dennis M. Pricolo, Trident Study No. 95, p. 73

67 Fletcher Crowe III, "The Soviet Union and the Turkish Straits, 1933-1945", p. 282. Truman later proposed the free and unrestricted navigation of all international waterways at the Potsdam Conference. It is interesting to note that the wording of this proposal in no way jeopardized American control of the Panama Canal. 
in which Turkey had a hand on Russia's throat." 68 Forrestal perceived this pressure as indicative of more sinister Soviet aims than simple access to the straits. An entry in his diary dated June 24, 1945 read:

The Russians last week renewed their pressure on Turkey for revision of the agreements of Montreux... with an indication that they would like to detach Turkey from the orbit of British influence. 69

American suspicions of the Soviet Union's intentions regarding Turkey and Greece increased markedly after Assistant Secretary of State Mark F. Ethridge returned from a tour of the Balkans in late autumn 1945. His assessment of the situation was bleak: Britain could no longer be expected to act as a deterrent to Soviet expansion; Russia specifically intended to dominate Greece and Turkey in order to obtain control of warm water ports. This report served to reinforce Truman's inherently belligerent, antiSoviet attitude which was rooted in the Wilsonian liberal capitalistic world view. Top secret reports from Central Europe and the Middle East also increased the Truman Administration's Russo-phobia. These reports indicated to the U.S. that the Soviets were attempting to establish hegemony along its perimeter and in areas which had been traditional focal

$68_{\text {Bruce }} \mathrm{R}$. Kuniholm, The Origins of the Cold War in the Near East (Princeton: Princeton University Press, 1980), p. 271

${ }^{69}$ Walter Mills, The Forrestal Diaries, p. 63 
points of Russian interests.70 The American Ambassador to Turkey reported that the Turks felt that they remained "one of the vital points in Soviet policy." 71 Ambassador Wilson reported that the Turkish Secretary General of the Foreign Office stated that to Turkey "the future looked dark but 'we would rather die on Turkish soil than be deported to Siberia. " 172

The Montreux Convention was never easy to interpret, and the Turks, perennial diplomatic tightrope walkers, were always sensitive about any revision of the straits agreement. Under the terms of the Montreux Convention, in case of war in which Turkey was a neutral, merchant ships (ordinarily armed during World War Two and so complicating matters of definition) were allowed free passage through the Straits, subject to minor charges and an inspection by Turkish health officials. Under these provisions, the Turks had permitted the passage of Axis ships into the Black sea during the war, a fact which infuriated the Russians. Warships of belligerent powers were prohibited from using the straits unless they were acting under the covenant of the League of Nations. The definitions utilized

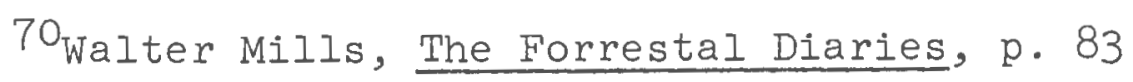

$7 I_{U}$. S. Department of State, Papers Relating to the Foreign Relations of the United States, 1946, VII, pp. 822823

72 Department of State Incoming Telegram (S) of 6 October 1946, Forrestal Papers, Vol. 4, p. 535 
by the Montreux Convention were functionally related to those employed in the naval limitations. treaties and related very little to the exigencies of modern warfare. Warships, for example, were very narrowly defined, while vessels of less than one hundred tons displacement were excluded from definition. As a consequence, the terms of the Montreux Convention did not deal with the new types of vessels which, although under one hundred tons, were definitely warlike in mission.

The real issue over the Straits was not the revision of the Montreux Convention. The terms of the Convention had generally worked to Russian advantage, particularly that article which prohibited the passage of belligerents during wartime. The Russian Navy and Merchant Marine were, at that time, small and of little consequence; furthermore, Soviet Naval units had been most active only in the Northern ports and the Vladivostok areas. Interest in controlling the Straits, however, had been a traditional concern (dating to the time of the Czars), but this concern for unlimited egress from the Black Sea had been deferred by Soviet leaders until the opportunity presented itself at the end of World War Two. 73 Certain historians viewed the Straits crisis as having evolved from a myriad of diverse issues:

73 Stephen Xydis, "The American Naval Visits to Greece and the Eastern Nediterranean in 1946: Their Impact on Soviet-American Relations" (Ph. D. Dissertation, Columbia University, 1956) p. 57 
historic Russian-Turkish antipathy which had intensified during the Second World War; Soviet determination to gain control of the strategic Dardanelles; and Stalin's inherited Georgian trait of hating everything Turkish except the tobacco. ${ }^{74}$ In a letter to a friend Admiral Leahy noted that the real crux of the problem of the Straits was never directly addressed: "everyone knew that the Russians desired control of this waterway. $" 75$

Some officials within the United States Government felt that the Soviets desired more than a settlement of the Montreux question. William Bullitt, former U. S. Ambassador to the Soviet Union, remarked in March 1946 that:

The notion that the Russians have to have the Dardanelles for reasons of commercial egress through warm waters had no substance...there could only be one objective in the effort to establish Russian influence on the Mediterranean littoral and that was to be able to sit athwart communications of the British Empire. 76

The U. S. Ambassador to.Turkey Edwin C. Wilson cabled the State Department on April 12, 1946 his assessment of the Russian pressures for revision of the Montreux Convention: The development of air power during the past war

74 Walter LaFeber, America, Russia and the Cold War, 1945-1975 (New York: John Wiley \& Son, Inc., 1976), p. 36

7.5 Bruce Kuniholm, The Origins of the cold war in Near East, p. 335

76 Forrestal Papers, Memorandum of a luncheon with William Bullitt, March 10, 1946, Vol 4, p. 920. Forrestal remarked that only he and "Bill" Bullitt can see the Russians for what they really were--bent on world domination. 
has greatly limited the value of the straits from a strategic viewpoint, The real Soviet objective towards Turkey is not revision of the regime of the Straits, but actual domination of Turkey In the vast security belt of the Soviet Union... Turkey constitutes the sole gap. Turkey maintains an independent foreign policy... and this the Soviet Union is unwilling to tolerate. The Soviet objective is to break down the present independent Turkish Government, and to establish in its place, a vassal or "friendly" regime in Turkey. 77

Wilson continued to support his contention by stating that, had the Soviets really desired a simple revision of the Montreux agreements, they would have accepted the United States proposal of November 2, 1945. Wilson alleged that this American plan recognized the privileged position of the Soviet Union and other Black Sea powers vis-a-vis the Straits and, in essence, granted the Black sea countries, acting in concert, control over the straits. ${ }^{78}$ The American plan was, however, perceived by the Soviets as maintaining and, in fact, guaranteeing Anglo-American predominance in the Eastern Mediterranean.

The Soviet Union continued to press Turkey during the months following the end of war in Europe. Criticisms of the Turkish Government in Soviet press and radio campaigns became more vigorous. ${ }^{79}$ Russia also demanded that

$77_{U}$. S. Department of State, Papers Relating to the Foreign Relations of the United States, 1946, VII, p. 821. Wilson's assessment of the situation in the Eastern Mediterranean was consistently anti-Soviet and pro-Turk. $7^{8}$ Ibid.

${ }^{79}$ Stephen Xydis, "American Naval Visits to Greece and the Eastern Mediterranean, 1946", p. 57 
Turkey retrocede the provinces of Kars and Ardahan. 80 Furthermore, in addition to the bilateral agreement on the Straits which the Soviets required of Turkey, Russia also pressured the Turks for the "positive guarantee" of Russian bases on Turkish soil. 81 This war of nerves continued, and on December 20, 1945, Soviet authorities sanctioned publication of Soviet claims to ten thousand square miles of Turkish territory stretching along the southern coast of the Black Sea for a distance of one hundred miles westward from the oil port of Batum. 82

As the international scene deteriorated, Forrestal continued working patiently for the reestablishment of the Mediterranean naval force. He felt that power applied economlcally, in advance of a crisis situation, would yield disproportionately greater results than allowing the situation to deteriorate to the point which would demand the use of force. Additionally, in early 1946, on the domestic political front, Forrestal was faced with another battle to stave off drastic Congressional cuts in the Navy's proposed

${ }^{80}$ Russia had invaded these provinces in 1806,1828 , 1855, and 1877. The first three times she was forced by the West to restore her conquests to the Ottoman Empire; the last time, she retained possession of then from 1877 until 1923. Except for this forty-three year period, the districts had been in Turkish possession for hundreds of years. 81 Global News Section, U. S. Naval Institute Proceedings, February 1946, p. 299 82 Ibid., p. 300 
budget and further reductions of an already demobilized fleet. What was eminently suited to both his international strategy and his domestic difficulties was the opportunity to prove that the modern Navy had a place in the scheme of American global mission. The Russian pressures on Turkey and the civil disturbances in Greece had become increasingly worrisome concerns for American foreign policy makers. Repeated requests by the Turks for some demonstrative token of United States interest and involvement in the Straits question and by the British for assistance in dealing with the riots and disturbances in Greece provided the perfect rationale for Forrestal's plans to send the USS Missouri and an accompanying task force to the Mediterranean. 
CHAPTER V

The United States Navy

in the Mediterranean, 1946

The Cruise of the USS Missouri

to Turkey and Its Impact

In early February 1946, Forrestal and Admirals Chester Nimitz and Forrest Sherman 83 took steps to ensure the gradual redeployment of naval forces to the Mediterranean. Forrestal conceived the idea of deploying the Eighth Fleet, normally stationed in the Atlantic, into the Mediterranean for training maneuvers. The presence of the Eighth Fleet in the politically sensitive Eastern Mediterranean was meant to act as a deterrent against soviet moves. In a letter to Rear Admiral B. H. Bieri, commander Task Force 125 (TF-125), Forrestal briefly discussed his rationale for suggesting that the Eighth Fleet conduct its spring exercise in the Mediterranean:

For your information, it is my hope that the American policy will be to have units of the American Navy sail in any waters in any part of the globe. I am anxious to get this established as a common practice so that the movements of our ships anywhere in the world will not be matter for excitement or speculation. It

${ }^{83}$ Admiral Chester Nimitz was the Chief of Naval Operations and Admiral Forrest Sherman was Deputy Chief of Naval Operations for Politico-Military Affairs. 
was with this in mind that I had first proposed to have the 8 th Fleet conduct its spring exercises in the Mediterranean itself. 84

The opportunity for expanding American naval involvement in the Mediterranean occurred in March 1946. This same month which witnessed the Churchill-Stalin exchange over the "Iron Curtain," the crisis over Iran, renewed pressure on Turkey, the collapse of the Greek election leading to renewed civil conflict also saw the first U. S. postwar naval demonstration. In March 1946, the United States Government returned the ashes of Mehmet Munir Ertugun, the late Turkish Ambassador to the United States, to Turkey aboard the "super-battleship" USS Missouri.

Who actually made the decision to utilize the USS Missouri to transport the ashes of Ambassador Ertugun is not certain. The choice was indicative, however, of the importance attached to the necessity of adequately "showing the flag". In the troubled Eastern Mediterranean. Under ordinary circumstances an Air Transport plane or a smaller naval unit would have been utilized to return the Ambassador's

84

Walter Mills; The Forrestal Diarles, p. 184. Rear Admiral Biere commanded TF-125 which included all American naval units in the Mediterranean. TF-125 was, in turn, part of the 12th Fleet which had previously only operated in Northern European waters but, in 1946, was expanded to include all naval units in Europe. For a schematic representations of the chain of command for naval forces in Europe prior to the establishment of the Sixth Fleet, see Appendix $B$. 
remains to Istanbul. For example, the ashes of Lord Lothian, the former British Ambassador to the United States, were returned to Britain in late 1945 on board a Navy cruiser, as protocol demanded. 85 Dean Acheson, the Undersecretary of State, wrote President Truman in January 1946 that the Turkish Ambassador's body be returned in the same manner:

Oral advice from the Navy indicates that a cruiser is available for the voyage to Istanbul and, if you approve, I shall confirm this with the Navy Department and offer the Turkish Government transportation of the Ambassador's remains accordingly: 86

It is apparent, however, that Forrestal and other Navy officials pressed for the use of a battleship. The Navy Department responded to the state Department inquiry that there was a cruiser shortage and that the battleship Missouri was the only ship available. Navy spokesmen were telling less than the truth: logs of the Norfolk, Virginia based cruisers, Houston and Portsmouth indicate that they were easily available for a cruise to the Mediterranean. 87 In any case, the choice of the battleship Missouri, symbolic of the American defeat of Japan and a mute reminder of the

\section{Dennis M. Pricolo, Trident Study No. 95, p. 37 86 Memorandum for the President from Dean Acheson,} Reproduced by Captain Guy Cave, USN, The Build-up of U. S. Naval Forces in the Mediterranean as an Instrument of Cold War Policy (Washington: The National War College, 1975), p. 85

87 Chief of Naval Operations' Ships' Card File, Operational Archives, U. S. Naval Academy Library, Annapolis, Maryland. 
the atomic arsenal of the United States, was a brillant piece of calculated showmanship. 88

The State Department announced on March 6, 1946 that the body of Ambassador Ertugun would be returned to Turkey on board the USS Missouri which would, on the return trip, call at Piraeus and other Mediterranean ports. The announcement received very little play in the press until it was disclosed two days later that the Soviet Union had formally asked the Turkish Government to cede certain districts to it as a precondition for settlement of the Straits problem. The significance of the deployment of the Missouri then made page one of the New York Times:

These demands were taken more seriously (in Washington) than almost any Soviet threat, because any attempt to seize these territories by force, it is felt here, would lead to war...against this background, there is considerable interest here in the decision to dispatch the new battleship Missouri. 89

Forrestal had conceived an impressive display when he suggested, and apparently received tacit approval, that a large part of Vice-Admiral Marc A. Mitscher's Eighth Fleet accompany the Missouri into the Mediterranean. The display of firepower would be awesome. The elements of the Eighth Fleet which would steam in company with the

88

Robert G. Albion and Robert Connery, Forrestal and the Navy, p. 186. One of Forrestal's aides recalled that the choice of the Missouri was readily acceptablein part because Truman came from the state of Missouri. It (the choice) was "a piece of calculated salesmanship." New York Times, March 8, 1946, p. 1 
Missouri were the newly commissioned attack aircraft carrier Franklin D. Roosevelt, the attack carrier Midway, several cruisers, and a variety of escorts. 90

Why final approval of this decision to send the Eighth Fleet was withdrawn and by whom is not clearly evident. What is certain, however, is that during the ten days between Forrestal's proposal to Secretary Byrnes and the State Department announcement of the Missouri's mission, Eighth Fleet maneuvers were changed from the Mediterranean to the Caribbean. While it may be conjecture that the rapid demobilization of the Navy and the need for units in the Far East caused the cancellation, ${ }^{91}$ there was also an ideological dispute involved in the decision. Certain prominent Washington officials indicated that they thought that the dispatch of so large and powerful a fleet would appear provocative to the Soviet Union on the heels of Administration speeches indicating a tougher policy towards Russia. Others felt that the world needed to grasp the ability of the United States "to concentrate great sea air power quickly." 92

90 Naval Organization Manual 1946; New York Times, March 18, 1946, p. 1

9l This possibility is unlikely for several reasons: (1) the Missouri encountered five destroyers enroute to the United states while she was in the Mediterranean, (2) scant five months later, the major units of the Eighth Fleet would make virtually the same cruise as did the Missouri earlier.

92 Stephen Xydis, "The American Naval Visits to Greece and the Eastern Mediterranean in 1946", p. 49 
The American and European press trumpeted the voyage of the Missouri as a symbol of American support for Greece and Turkey. Walter Lippmann wrote three days following the official announcement of the Missouri's mission that:

As everyone knows, the choice of this ship and the timing of its voyage coincide with the mounting crisis in the Middle East constitutes a political demonstration. This action is meant to show that the United States has a real, not merely theorectical, interest in the Mediterranean, for when a great power sends a battleship to a disputed area, in the language of diplomacy that means it intends to participate in the settlement. 93

The Missouri left Bayonne, New Jersey on March 2l, 1946. It transitted the Straits of Gibraltar on April 1, becoming the first American battleship to enter Mediterranean waters. 94 The cruiser Providence and the destroyer Power joined the Missouri at Naples, and acting under orders from the Secretary of the Navy, accompanied the Missouri through the Dardanelles.

The Missouri, the Providence and the Power, accompanied by three Turkish destroyers, arrived at Istanbul on April 5, 1946. The reception accorded the ship was tumultuous. Huge crowds manned Istanbul's Byzantine Wall to see the coming of the "Mighty Mo". "Welcome Missouri" was emblazoned in electric lights on the lighthouse at the entrance to Istanbul harbor. The Naval Attache noted that

\section{New York Herald Tribune, March 9, 1946, p. 13 \\ 94 Stephen Xydis, "The American Naval Visits to} Greece and the Eastern Mediterranean in 1946", p. 52 
"people came from the Eastern provinces to see the ships, and peasants reported traveling fifty mịles to see Admiral Hewitt (officer in charge of the mission) at the stations along the route to Ankara." 95 To commemorate the visit of the Missouri, the Turkish Government issued special Missouri stamps and cigarettes. As long as one year after the visit, Rear Admiral Marc Ingliss, Director of Naval Intelligence for Europe, reported being bombarded by questions from the common people of Turkey concerning the Missouri's visit while on a tour of the Eastern Mediterranean trouble spots. 96 U.S. Ambassador to Turkey Edwin Wilson wrote Secretary of State Byrnes that the overwhelming reception given the Missouri could be explained by Turkish hopes that the United States had established an independent policy in the Near and Middle East based on its own interests (apparently Wilson assumed that the Turks preferred American interest to either British or Russian). Wilson continued to stress the importance of the visit:

Translated into specific terms applying to Turkey foregoing (the visit of the Missourj.) means to the Turks that the US has now decided that its own interest in the area require it to oppose any effort by USSR to destroy Turk independence and integrity. This because if USSR allowed to destroy Turk independence and set up "friendly" regime here, nothing could prevent

95 Letters and Dispatches Relating to the Mediterranean Voyage of the Missouri, Operational Archives, U. S. Naval Academy Library, Annapolis, Maryland

96 Ibid. 
Soviets from ascending to Suez and once this occurs another world conflict becomes inevitable. 97

According to American newspaper commentaries concerning the visit, the Turkish Goverment made a concerted effort to characterize the Missouri's visit as merely a special gesture of goodwill to a friendly country. These reports further stated that many Turks were disappointed by the State Department denial of the suggestion that the battleship's voyage was intended to demonstrate American support for Turkey against the Soviet Union.98 Official Turkish statements had a cautious tone. When the Turkish premier, Sukru Saracoglou, was asked whether he considered the Missouri's visit an American show of force against the Soviet Union, he stated that the United States has answered that question by "stating to the world that it stands with the charter of the United Nations. "99

European newspapers linked the USS Missouri's presence in Istanbul with President Truman's public statement that the United States was the strongest nation in the world and intended to remain so. ${ }^{100}$ The British Government

${ }^{97}$ U. S. Department of State, Papers Relating to the Foreign Relations of the United states, 1946, VII, . 283

98 New York Times, April 6, 1946, p. 4



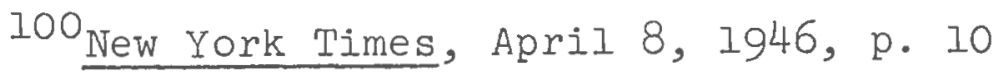


was particularly interested in American naval visits to the Eastern Mediterranean, hoping for as strong a presence as possible. Great Britain, suffering severe economic debility, required and desired a strong surrogate to protect her interests in the Eastern Mediterranean area. When Winston Churchill was informed by Forrestal of the deployment of the USS Missouri without the company of the Eighth Fleet, he stated only that he was disappointed that it had not been accompanied by a task force because "a gesture of power not fully implemented is almost less effective than no gesture at all." Churchill suggested that to make the visit diplomatically effective "the entire task force should sail into the Sea of Marmara."101

On a visit to England in July 1946, Forrestal had occasion to dine with First Lord of the Admiralty A. V. Alexander and First Sea Lord Sir John Cunningham. Both Cunningham and Alexander also expressed disappointment that the United States did not "go through with the proposal to have Mitscher's Eighth Fleet train in the Mediterranean. "102

The presence of the USS Missouri in the waters of Istanbul at the height of the Soviet pressure upon Turkey was a gesture of power underlying not only American p. 145 .

\section{${ }^{101}$ Forrestal Papers, Unpublished Diaries, Vol. 4,} 102 Ibid., p. 1166. 
interests in the Near and Middle East but also of a growing closeness in Turkish-American relations in an area of the world where no ground troops were capable of long opposing the Soviet Red Army. Furthermore, it was the symbolic return of American power to an area which had seen some of the first American successes at sea. It was representative of the new order, a reversal of long-standing tradition. America would no longer rely upon British sea power in the Mediterranean. The United States, once maritime understudy to the world's greatest sea power, had de facto replaced her British counterpart.

\section{The Cruise of the USS Missouri to Greece and Its Impact}

The Missouri left Istanbul on April 9, 1946 after a highly successful visit. On her return voyage, she was scheduled to stop at Piraeus (port of Athens), Algiers, Naples, and Tangiers. Of these visits, the most important, diplomatically, was Greece. Greece had been under serious pressure from the Soviet Union to drop its claims to the Dodecanese Islands and accede to Russian requests for a repair base for the Soviet Merchant Fleet. 103 Severe economic dislocation within Greece together with the ravages of a complex civil war made the Greek Government particularly susceptible to external pressure, whether those pressures

\section{$103_{\text {The Dodocanese Islands, owned by Italy since }}$} the division of the Ottoman Empire, were claimed by Greece. 
be Russian, British, or American.

Great Britain had traditionally maintained a sphere of influence in Greece. ${ }^{104}$ Faced with the virtually insurmountable problems of maintaining an unpopular, pro-British government, of feeding thousands of starving Greeks and of consolidating Greek economic problems, Britain could barely maintain order in the war-ravaged country. To understand the situation in Greece, it is first necessary to grasp the fragmented and bitter nature of the civil war. The king had fled Greece when Germany occupied the country in 1941. He remained in England during the war,establishing a government-in-exile. The Greek people organized into several resistance groups--the EIAS (leftist and intensely nationalistic), the EAM (ELAS supporting political organization), the KKE (the Greek Communist Party), and the EDES (conservative and royalist). The ambigious British policy which led. to Englandr to support the EIAS military activities against the Germans while opposing its political aims by strenthening the pro-Royalist, reactionary elements of the EDES caused an intensely chaotic political climate within Greece which sporadically exploded into bloody civil war. Although initially and officially disinterested, the United States began gradually to fill the power vacuum left by the British weakness. In December 1945, when the

${ }^{104}$ British interest in Greece largely stem from its position as part of the communications and logistics link 
cruiser Providence made a call at Piraeus, it served to focus attention on the power of the United States:

Everything on the ship symbolizes the tremendous power which arises majestically toward world hegemony. America has shown itself not only the first factor of the people's freedom. Mistress of the oceans and of the seas, she has the power to become the arbiter every moment in disputes among nations. 105

This visit was followed by monetary and by other tokens of American interest. In January 1946, the United States loaned the Greek Government \$25 million for the purchase of reconstruction goods. Another loan followed in February for $\$ 10$ million for the purchase of surplus army goods and in March, another $\$ 45$ million for surplus American vessels. 106

Greek governmental instability continued to increase in the early months of 1946. The Soviet Union continued to request bases on Greek-claimed territory; the leftist and communist rebels continued to attack the existing pro-Western government (aided in part by Yugoslavia). The United States and Great Britain viewed Tito and Yugoslavia as puppets of the Soviet Union and, therefore, saw the hand of Moscow in the repeated rounds of Greek civil

with the "jewel of the British Empire", India.

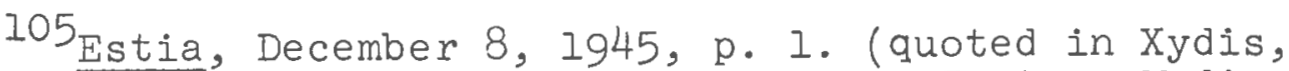
"The American Naval Visits to Greece. and the Eastern Mediterranean", p. 77).

106 Department of State Bulletin, XIV, February 3, 1946, p. 155 . 
war. The United States and Great Britain feared that the Soviet Union would succeed in placing a. leftist government in power in power in Greece after the royal plebicite in September 1946. It was with this in mind that the American Embassy in Athens sent a communication to the Royal Ministry for Foreign Affairs "to ask whether the Royal Hellenic Government would be agreeable to receiving a visit from the USS Missouri from April 10 to April 13 accompanied by a destroyer." 107 The Greek Government consented to the visit, obviously quite pleased with the renewal of American interest in Greece. 108

The Missouri's visit to Athens was more exuberant than that to Istanbul. The great battleship was accompanied by her two escorts, Providence and Power, a Turkish destroyer and two Greek destroyers. Admiral Hewitt had visited Athens before as a Passed Midshipman (a Midshipman who graduated from Annapolis and was waiting for an opening in the Ensigns' list) on the old battleship Missouri during the cruise of the Great White Fleet. The Greek Government was made well aware of this fact by the American Embassy and, consequently, Hewitt was treated with particular accord. 109

107 Stephen Xydis, "The American Naval Visits to Greece and the Eastern Mediterranean in 1946", p. 85. 108 109 Ibid., pp. 86-87. Admiral H. K. Hewitt Oral History Transcript, Special Collections Section, U. S. Naval Academy Library, Annapolis, Maryland. 
Though Russian pressure for territorial concessions and leftist threats from civil war must have been uppermost in the minds of Greek politicians, none contradicted Hewitt's statement that the visit of: the Missouri was simply a courtesy visit, not a political one aimed at the Soviets. The Greek press, however, was not as restrained as had been the Turkish press nor as was the Greek Government in ascribing political motives behind the visit. From newspapers on the far right to those on the far left, the political significance of the visit of the American warships dominated the reports and editorials. 110

Some newspapers were cautiously political. Ethnos, a conservative paper, noted that "the Missouri is one of the sedatives of the warlike neurosis which troubles tired humanity after a few months of peace." The ultra-royalist evening paper Akropolis bluntly discussed the political motives of the visit:

Touch wood, our Ambassador in Washington does not die like our Turkish colleague. Thus, the arrival of the American colossus (the Missouri) at Piraeus does not have the same transparent justification as its trip to Istanbul. However, the motives and the purpose of the visit are the same: Around us here and in the Balkans hovers the great Russian shadow. So the American comes here, too, to tell us: "hold tight, and you may be sure we are with you.

The leftists papers' commentaries on the visit of

$110 \mathrm{AlI}$ Greek newspaper quotations may be found in Stephen Xydis, "The American Naval Visits to Greece and the Eastern Mediterranean, 1946", pp. 89-111. Mr. Xydis served as a Greek consular official in the United States. 
the Missouri differed completely in tone and content from those at the other end of the political.spectrum. The official newspaper of the leftist party, the EAM, chose to ignore completely the visit; the KKE paper welcomed "with joy the men and officers of the Great American Republic" but expressed unease at the "unconcealed imperialistic interests" of the United States in the postwar period. The Greek people flocked to see the battleship, the symbol of America's victory in the Pacific. On April 11 and 12, for four hours each day, the warship was open to one thousand visitors each day, but only those with special invitations. The crowds without invitations who simply went to gaze upon the American ships were incredibly large, causing one Greek writer to remark that "the Missouri will remain unforgettable to those who saw it, but unforgettable too, to those who went to see it...but didn't." 11 l The USS Missouri, during its four day visit to Athens, received a welcome of considerable warmth by the government officials, the press, and the people. Even the Communist newspaper acknowledged this visit by greeting the American warship warmly, although gently disapproving of American foreign policy trends. The Missouri's visit to Greek waters had all the hallmarks of an act of pure prestige.

${ }^{11}$ Stephen Xydis, "The American Naval Visits to Greece and the Eastern Mediterranean", p. 89 
Polltical allusions can barely be read between the lines of official pronouncements of either government. Indeed, all statements by the Greek Government alluded to further economic aid from the United States rather than direct military assistance.

Great Britain required American naval assistance to counter Soviet moves in the Near and Middle East. It is uncertain, however, whether the Soviet Union viewed these U. S. maneuvers as threatening. Soviet news sources initially ignored the American naval presence in the Mediterranean. In fact, although the voyage of the Missouri could be characterized as blatant "gunboat diplomacy," the Soviet Union made no mention of the Missouri for three weeks following her visits. However, Rizospastis, a radical Greek Communist newspaper, attacked not only the visit of the Missouri but also what it called American "atom diplomacy," thus betraying an awareness of the atomic power symbolized by the Missouri. 112

When the Soviet press finally recognized that a major United. States warship had been cruising the Eastern Mediterranean, criticism was directed not at the United States but at Turkey and Greece. Choosing to place the visit in the most favorable light possible, the Soviet

112 Stephen Xydis, "The American Naval Visits to Greece and the Eastern Mediterranean," p. 106. Xydis contended that Rizospastis was operating under orders from Moscow. 
state paper Izvestiya chided the Turks for placing too great an emphasis on political implications of the visit. The Soviet attitude was expressed thus:

Take it easy, Turks. Don't make a sensation, a boom, out of the Missouri's visit to Istanbul. Remember the original plan had been to send the whole Eighth Fleet there. The visit was just what it was said to be: a normal courtesy visit to return the body of the Turkish Ambassador to Washington. It was due no political consideration. 113

In further attempts to reduce the morale-building effects of the visit on both Greece and Turkey, Moscow radio, in vernacular broadcasts, dismissed as "saber-rattling" advocacy in certain American newspapers of the "need for protecting United States interests in all corners of the globe, even as far as the Mediterranean. "II4

Regardless of how the Soviets attempted to reduce the impact of the Missouri's visit to the Eastern Mediterranean, it did, in fact, prompt a vitrolic response little more than a month later. During a dinner at the Soviet Embassy for Secretary of State Byrnes and a few advisors, the Soviet Ambassador to the United States, Andrei Vishinsky, made an acidic attack upon American "imperialist expansion" and charged that the United States was seeking military bases in Turkey, Greece and Egypt--the very countries which were on the itinerary of the Missouri's voyage.

$$
\begin{aligned}
& 113_{\text {Ibid., p. } 111} \\
& 114 \text { Ibid., p. } 109 \\
& 115 \text { Ibid., p. } 110
\end{aligned}
$$


It appeared that the voyage of the Missouri did precipitate other tangible accomplishments. In addition to provoking Soviet outbursts, for example, shortly after the Missouri's visit, the Turkish crisis defused and Soviet troops were withdrawn from the border. As Forrestal remarked before a Senate Foreign Relations Committee on March 13, 1947:

Last summer, when the Russians began making their representations to Turkey on the Dardanelles, the appearance of American war vessels on the Mediterranean were followed by the first amiable utterances of Premier Stalin. 116

More than simply defusing the current crisis in the Near and Middle East, however, the Missourl initiated the reemergence of the United States Navy in power in an area of the world which many began to perceive as vital to the national interests of the United States. C. L. Sulzberger, in a feature article in the New York Times, spotlighted this emerging realization that the United States could no longer rely upon Great Britain to protect Western interests in that area:

...the triangle roughly bordered by the Adriatic, the Caspian, and the Red Sea (are) where the vital interests of the United States, Great Britain, and the Union of Soviet Socialists Republic meet. The actual frontier of what might be termed the present spheres of interest runs along the northern boundaries of Greece and Turkey, the eastern borders of Turkey and somewhere through the middle of Iran, in the vicinity of the zone fixed

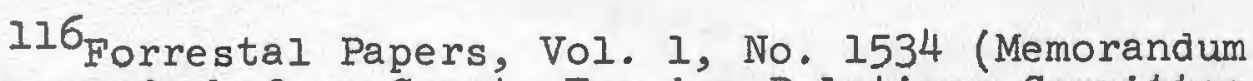
of Remarks made before Senate Forelgn Relations Committee, March 13, 1947). 
by Britain and Russia in 1907.

There are three basic reasons for the vital interests in this large area. These are, in order of importance; (1) national security, (2) international political influence, (3) petroleum. 117

Sulzberger went on to list the specific reasons for the United States interests in the area. The United States had vital air bases in the Middle East, specifically in Dharan. Furthermore, the important strategic oil reserves were in Saudi Arabia, and it was in the national interests of the United States to prevent the formation of any zone of political influence there, "commanded and controlled by any other power."Il8 Using the allusion of a pie, Sulzberger characterized Greece, Turkey, and Iran as the crust of the Middle Eastern pie--the only countries of sufficient strength to resist Soviet pressures. The remaining Middle East was viewed as "soft as mush all the way down to the Suez."119 Sulzberger proposed that the United States assist in making the "crust" stronger in order to prevent the penetration of the Soviet Union to the Red Sea. 120

The cruise of the "Mighty Mo" served as a warning

117C. I. Sulzberger, "Steady Soviet Pressure Expected in the Near East," New York Times, April 17, 1946, p. 6

$$
\begin{aligned}
& { }^{118} \text { Ibid. } \\
& { }^{119_{\text {Ibid. }} .} \\
& { }^{120} \text { Ibid. }
\end{aligned}
$$


to the Soviets that the U. S. viewed the Soviet Union as having reached the outer boundaries of its expansion and that the United States would consider further moves as going beyond legitimate and acceptable soviet interests. Furthermore, the consolidation of American global predominance dictated that a perceptible and powerful image of United States' military might be projected in all corners of the globe. The cruise of the Missouri provided just such a demonstration. The acclamation received by the visit from all quarters--British, Turkish, and Greek Governments--and the attention directed by the Soviet Union to the cruise set the stage for new demonstrations of American prestige and power in the Eastern Mediterranean. 
The Build-up of U. S. Naval Forces in the Mediterranean

For two months following the Missouri voyage, American naval operations in the Mediterranean reverted to their previous low level of activity. Rear Admiral Bernard Bieri, who took command of TF-125 in June 1946, was given no orders save a vague directive to support U. S. occupation forces in Europe. Bieri continually asked the State Department for directives concerning the effective uses of the naval presence in the Mediterranean. Forrestal lamented in July 1946 that:

The State Department is inclined to stand aloof from military people and to be unaware of the very great influence that the Navy in particular can exercise in Europe. Its prestige is high, the record of its accomplishments in the Pacific is widely known and its personnel in general have been disciplined and of good conduct whenever they have been in contact with Europeans. The Navy people need directions if they are to be effective. 121

In July when Forrestal again suggested that the United States send casual cruisers unannounced into the Mediterranean for the purpose of establishing the custom of flying the flag in those waters, Secretary of State

121

Forrestal Papers, Unpublished Diaries, No. 1534, Memorandum of Meeting with Chief of Naval Intelligence for Europe, July 20, 1946. 
Brynes agreed. The impressive reception of the Missouri and her escorts had convinced Byrnes that the naval displays were an important component of the diplomatic maneuvering which was taking place in Europe.

Forrestal had persisted in pressing the issue of establishing a standing naval force in the Mediterranean because he feared that the Soviet Union could initiate an incident which would require the United States to back up its diplomatic notes with force. He commented that:

The State Department love to run the ball until it gets too hot to handle. Then, without calling the signals, it is swiftly passed to the military, who are then expected to make a touchdown. 122

He further requested Admiral James Ramsey, Deputy Chief of Naval Operations, to prepare a brief of U. S. capabilities in the event of hostilities in Europe. The brief showed the Navy to be dangerously unprepared to meet mission requirements in the event of conflict. Demobilization had so reduced the number of personnel in the Navy that "a very large number of vessels in the active fleet cannot go to sea because of the lack of competent personnel." 123

Forrestal wasted little time in arranging imple-

\section{Walter Mills, The Forrestal Diaries, p. 190 123 Forrestal Papers, Unpublished Diaries No. 1222 ;} Memorandum of a Joint Chiefs of Staff meeting, August 22, 1946. Forrestal also noted that the fleet oiler catoctin had to borrow personnel in order to shift piers and even then, a minor accident accurred. 
mentation of Byrnes' permission to send additional ships to the Mediterranean. He ordered the attack carrier FrankIin D. Roosevelt, the cruiser Iittle Rock, and the destroyer escorts Cone, New, Corry, Noa, and Warrington--hardly the "casual" approved by Byrnes--to make calls in major Mediterranean ports. The press release announcing the deployment stated that the visits were at the expressed request of the State Department "as an insurance against civil disturbances in Greece. "124 However, the Navy Department apparently had considerable responsibility for the decision to send the Roosevelt and her escorts. A dispatch, from Admiral Connolly, Commander TF-125, to Forrestal, requested the presence of the American warships, particularly the "FDR" which he indicated would be "a tremendously helpful and stabilizing influence." 125

The Roosevelt's reception in Athens was not nearly as festive as that given the Missouri five months earlier. In addition to continued Russian pressure for concessions, the Greeks had endured five months of new civil war and the Greek economy was in shambles. Greece was spiritually exhausted and once again the United States Government

124 New York Times, August 27, 1946, p. 4. Russian spokesmen accused the United States of attempting to influence the voting in the Greek plebiscite by such a conspicuous display of power. The visit of the Roosevelt received such wide play in the press days before the election. The Roosevelt had been used a few months earlier to "impress" the Portuguese out of their leftist leanings.

$$
\text { 125Walter Nills, The Forrestal Diaries, p. } 89
$$


officially denied that the visit could be more than simple courtesy call. visit to Istanbul and Athens, the political significance of the port calls of the Roosevelt and her escorts (designated by the Navy as Carrier Division one) received widespread attention from the press, despite state and Navy efforts to downplay the political aspects of the deployment. Items in both national and international newspapers reiterated that the build-up of American naval forces in European waters was part of a deliberate plan to reinforce American diplomacy by shows of strength. 126 The New York Times commented upon the visit thus:

The FDR, largest and most powerful plane carrier in the world... is headed for Greece as a gesture of friendship on a routine training cruise. Officially, it is pure coincidence that the Roosevelt will anchor at what happens to be the height of the Yugoslav and Bulgarian pressure on Greece, but our ships do manage to get around those European trouble spots. 127

The Roosevelt's voyage was intended to intimidate the Soviet Union. However, the United States attempted to allow the Soviets some maneuvering room in its interpretation of the cruises. Undersecretary of State Dean Acheson denied to the press that the cruise of the Roosevelt was meant to be anything else but a goodwill visit to the

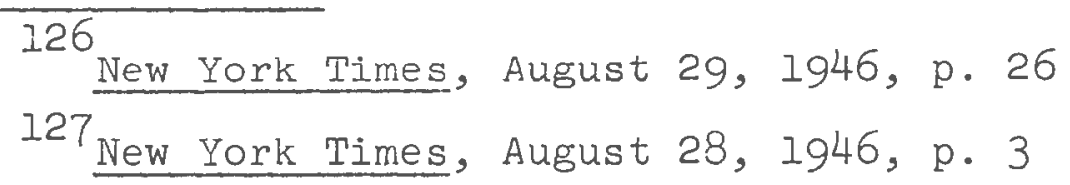


Eastern Mediterranean. Nevertheless, there was no doubt in either Moscow or Washington exactly why Roosevelt was making her Mediterranean circuit.

The visits hardly went unnoticed in the European press or within European governments. French newspapers commented on the importance that the United States attached to Near East oil fields, making a clear connection between the Soviet demands in the area and the renewal of American presence in the Mediterranean. The English, on the other hand, expressed both public and private pleasure at the idea of the American naval demonstrations, even to the point of lamenting that the demonstrations had not been on a grander scale. However, while supporting the American initiative, they also took pains to ensure that British vessels were in Piraeus when the Missouri and the Roosevelt visited Greece in order that the Union Jack be as conspicuously present as was the Stars and Stripes. 129

The reactions of the Navy Department officials indicated that the forces in the Mediterranean were not temporary in nature. Acting Chief of Naval Operations dewitt Clinton Ramsey asserted that although aggression was the farthest thing from the Navy's mind, the Mediterranean

${ }^{128}$ New York Times, August 28, 1946, p. 2

129 Stephen Xydis, "The American Naval Visits to Greece and the Eastern Mediterranean in 1946", pp. 123-137 
was a free sea and the Navy would not be kept from carrying out its mission due to allegations by other powers that its presence in the area was an attempt to influence events. Admiral William "Bull" Halsey bluntly stated, during a press conference on board the Roosevelt in Naples harbor, that:

Freedom of the seas is one of the oldest policies of the Government of the United States of America has maintained since its inception. We demand the right to go anywhere at any time. It is nobody's damn business where we go. We can go anywhere we please... we shall continue to demand the freedom of the seas remain unrestricted. 130

The American press continued to carry stories concerning the naval movements in the Mediterranean, commenting in detail about their anti-Soviet character. Admiral

Cassady, Commander Carrier Division One, granted an interview in Naples in which he stated

...that the plan of the American squadron's Mediterranean trip, which the Navy Department worked out in collaboration with the state Department, originated in part at least, from the desire to protect the distant frontiers of the United States. 131

Admiral Cassady also intimated that the Roosevelt carried a certain secret weapon (the A-bomb?), but certainly "not for aggressive purposes." 132

${ }^{130}$ New York Times, August 29, 1946, p. 1

${ }^{13}{ }^{1}$ Stephen Xydis, "The American Naval Visits to Greece and the Eastern Mediterranean, 1946", p. 145

132 Dennis M. Pricolo, Trident Study No. 95, p. 91 
These comments caused such a furor amid European diplomatic circles that Forrestal, during a SWNCC meeting, recommended that

all task force commanders going into foreign waters be briefed on the political situation in those areas and that (those commanders) be instructed to grant no interviews except on specific questions which should be written out and given to them before answering.

He further requested that the Navy be authorized to prepare an abstract, without attribution to the state Department, of American policy in these areas. 133

On September 5, World Report carried a detailed analysis of U. S. diplomatic and naval activities in the European area:

The United States is making her largest show of force since the war's end. This is being done by diplomatic notes calling Yugoslavia and Poland to account for policies the United States does not like, by diplomatic action asserting an American interest in control of Europe's waterways, and by sending the largest United States fleet in peacetime into the Mediterranean... The objectives of all this American action is to check Soviet expansion.

United States Naval power, now in the Mediterranean, is on display to re-enforce United States State Department notes on the issue of waterways, particularly the Dardanelles. The aircraft carrier Franklin D. Roosevelt is showing the flag east of Gibraltar, while in london Admiral Marc Mitscher, commander of the Twelfth Fleet, says that the United States will maintain an enlarged fleet in the Mediterranean for some time to come. 134

133 Forrestal Papers, Unpublished Diaries, Vol 5, No. 1237, Memorandum of a SWNCC Meeting of September 4, 1946.

134 "US Displays Force in Europe to Check Russian Expansion: Diplomatic Moves and Fleet Serve as Warning", World Report, I, 5 September 1946, pp. 5-6 
The United States News: commented on the role of the warships in the Mediterranean:

Regardless of its outcome, the role of Carrier Division one as the country's "big stick" in the Mediterranean sets the pattern for employment of the Navy in United States diplomacy in the coming years...This country has again begun to use its powerful naval forces as a "big stick" in its relations with other nations, notably Russia. U. S. warships now in the Mediterranean may play a profound role in the outcome of the present tense situation there. In any case, they are proof that the U. S. means to back up its diplomacy with a display of military force. 135

The Soviets had generally avoided any direct mention of the appearance of the U. S. Navy in force in the Mediterranean. However, the political implications of Carrier Division one were impossible to ignore. The announced schedule of port calls for the Roosevelt and her escorts had to appear coercive to the Russians, especially following so rapidly after the delivery of a strong American note on the Soviet conditions for renegotiation of the Montreux Convention. ${ }^{136}$ The Soviet press strongly criticized the "gangster diplomacy" of the new round of U. S. Naval demonstrations, commenting that the United States ships threaten waters of the Mediterranean, Norwegian and Baltic Seas, "which have no connexion (sic) with the defense of the United States of America itself." 137

135"Our Naval 'Big Stick' Abroad: A Warning Against Aggression", U. S. News, September 13, 1946, pp. 22-23 136 Stephen Xydis, "The American Naval Visits to Greece and the Eastern Mediterranean in 1946", p. 152

$$
137_{\text {Ibid., p. }} 165
$$


The Soviet state newspaper Izvestiya commented upon the presence of the Roosevelt in Greek waters thus:

It is doubtful whether the Greek or other peoples will show greater reverence for the late President, if he appears to them in the guise of an aircraft carrier. This ship is at sea for an entirely different, a nonRooseveltian policy... remote from the goodwill about which $\mathrm{Mr}$. Acheson spoke. 138

Further statements $i$ in the Soviet press continued to stress the expansive nature of the American Naval visits. A Soviet Rear Adniral wrote Praevda that

America is intending to maintain a permanent squadron in these waters (the Mediterranean), although she does not possess a single patch of territory on the shores of the Mediterranean. America's desire to stress her interests in the Mediterranean is indicated by the demonstrative visits to ports in that sea which are being made with increasing frequency of late by American warships, sometimes by whole squadrons. 139

The visit of the Roosevelt to Athens provoked such a response from the Soviet press for several reasons. The ship itself, the largest aircraft carrier in the world, was an impressive demonstration. On her decks, one hundred twenty-three planes--attack bombers, dive bombers, fighters-were undeniable evidence of the reach of American sea air power. 140 However, it was the psychological impact of the

$$
\begin{aligned}
& 138_{\text {Ibid., p. }} 158 \\
& { }^{139} \text { Ibid., p. } 162
\end{aligned}
$$

140 The U. S. sought and the Greek Government granted permission for an air parade of all 123 airplanes from the Roosevelt. The fly-by was cancelled abruptly, and press speculation indicated that there was concern in state Department circles that such a demonstration would have appeared provocative. 
naval presence that was not lost either on American strategists or on Russian propogandists. Comments in an American periodical accurately identified the thrust of the naval visits:

What the Navy will do in case of aggression by Russia or Yugoslavia is less important than the psychological effect of its presence there. If hostilities broke out, guns and planes of these ships could be used effectively against only coastal targets....

Effects of these maneuvers on the delicate questions of Palestine, Egypt, and Greece, and on the more explosive situation in the Dardanelles, the Middle East oil fields and Trieste, will largely depend on Soviet reaction on the psychological effect of such visible American power. 141

${ }^{14} 1_{\text {U. S. News, }}$, September 13, 1946, p. 23 
The Establishment of the United

States Sixth Fleet

Throughout 1946, Forrestal continued to work towards the establishment of a permanent naval squadron in the Mediterranean Sea. The obvious diplomatic successes of the Missouri, the Roosevelt, and the other "casual cruisers" provided hard evidence for Forrestal's fight to construct a relevant postwar Navy. Two weeks following the resignation of Secretary of Commerce Henry Wallace 142 , Forrestal issued a statement acknowledging publicly the political purpose of the naval movements in the Mediterranean and formally establishing a permanent naval commitment in those waters. Forrestal was so pleased with the culmination of his efforts to reestablish the credibility of the Navy that he troubled to enter the statement in his diary:

The gist of it was: Units of the American Fleet have been in the Mediterranean and will continue to be there in the future to (1) support American forces in Europe, (2) carry out American policy and diplomacy, (3) for purposes of experience, morale, and education of personnel of the fleet. 143

142 Wallace had been the leading advocate within the Truman Administration of a conciliatory attitude towards the Soviets. His departure signalled increasing U.S. belligerency. $30,1946$.

143 Forrestal Papers, Vol.2, No. 1233 of September 
Elements of Forrestal's statement were contained in a top secret report written by the office of the chief of Naval Operations in July 1946 regarding the creation of a permanent naval presence in the Mediterranean:

Certainly as long as we have troops in Europe, and probably as long thereafter as the present Soviet policies remain unchanged we should maintain in the Eastern Atlantic and Mediterranean an adequate Naval Force capable of rapid reinforcement from the Western Atlantic. The reinforcements would include carrier elements. It is recommended that no U. S. bases be permanently established due to the difficulties in protecting them. Utilization of existing British naval ports should be sufficient. 144

The United States Navy cleacly was preparing to assume the former British role as the preeminent power in the Mediterranean on the apparent assumption that the British would willingly step aside.

American newspapers welcomed Forrestal's statement as a "firm and clear statement of naval policy"145 and a "formal expression of the politico-military policy being pursued by the (Truman) Administration. Its mission is avowedly the support of American rights and interests in those vital matters. "146 Forrestal himself viewed the naval .

144 CNO TOp Secret Report dated 23 July 1946--Furthermore, an intelligence message dtg $141258 \mathrm{Z}$ Feb $4 \overline{6}$ from Assistant Naval Attache Turkey discussed the perceptions of the Soviets that British bases at Malta and Cyprus were being turned over to the United States.

torial.

145 New York Times, October 1, 1946, editorial

146 New York Herald Tribune, October 1, 1946, Edi- 
policy he had constructed as extraordinarily productive: "the appearance of American war vessels, in the Mediterranean was followed by the first amiable utterances of Premier Stalin." 147

The policy was immediately implemented. At the beginning of 1946, there were only three U. S. warships in the Mediterranean. By February 1947, one year after the original cruise of the Missouri, a total of two aircraft carriers, the Randolph and the Roosevelt, seven cruisers, among them the Providence and the Little Rock, eighteen destroyers, and four auxiliary ships were present in the Mediterranean and had made port visits to all ports of any size or consequence, a total of over forty ports.

In early 1947, the American naval units were still organized as Task Force 125 (also designated U. S. Naval Forces, Mediterranean) under Admiral Bieri. In January 1947, TF-1.25 was considerably strengthened by the inclusion of an Amphibious Task Group complete with a Marine Amphibious Unit (MAU). The American Naval presence in the Mediterranean now had the capability of intervening with land forces, that is, the capability of projecting power ashore. This amphibious force normally rotated between the United States

\footnotetext{
147 Walter Mills, The Forrestal Diaries, p. 231 148 Dennis M. Pricolo, Trident Study No. 95, pp. $99-110$
} 
and the Mediterranean every four months. The carriers cruised the Mediterranean for two or three months, while cruisers and destroyers remained six months before returning to the United States. 149

Of additional significance for the U. S. Navy in the Mediterranean was the choice in January 1948 of ViceAdmiral Forrest Sherman as the new Mediterranean commander. The choice of Sherman as head of the Navy's Mediterranean arm was truly indicative of the Navy's commitment to remain in strength in the Mediterranean. The press was quick to point this out, noting that Sherman had been instrumental in bringing the case for a strong Navy to the Congress and to the public. Furthermore, he had headed the strategic board which had developed War Plan PINCHER and had been selected to present it to President Truman. ${ }^{150}$ In many ways, Sherman was Forrestal's extension in the development of a permanent naval commitment to the Mediterranean. Sherman was consistently present whenever Forrestal was required to defend the Navy's presence in the Mediterranean. It was Sherman who emphasized that there was a direct relationship between the success of the European Recovery Program and the maintenance of a strong naval force-in-being,

$$
\begin{aligned}
& 149_{\text {Ibid. }} . \\
& 150_{\text {Ibid. }} .
\end{aligned}
$$


particularly in the Mediterranean--a somewhat extreme statement but nevertheless indicative of Sherman's intense dedication to maintaining a strong, vigorous Navy in Mediterranean waters.

Realizing that the increased importance of Task Force 125 (as well as the fact that TF-125 was one of the premier naval forces in the world), it was renamed the Sixth Task Fleet on July 1, 1948. On February 12, 1950, the American Naval force in the Mediterranean was officially designated the "United States Sixth Fleet." Along with the Seventh Fleet, it constitutes the two main naval forces continuously deployed in forward areas.

The United States Navy owes its considerable presence in the Mediterranean and, indeed, in the rest of the world's waters to James V. Forrestal. An aide described Forrestal's role in establishing this formidable extension of United States power thus:

Forrestal, old boxer that he was, exercised his consummate skill at political infighting and eventually succeeded in getting his Task Force into the Mediterranean. 151

151 Robert Albion and Robert Connery, Forrestal and the Navy, p. 168 
CHAPTER VIII

Conclusion

The estabIishment of the U. S. Sixth Fleet in the Mediterranean demonstrated a successful application of naval presence in peacetime. The naval demonstration was expressly designed to deter the Soviet Union from further encroachment in the Mediterranean and to align the power realities in the Mediterranean to America's best interests. When the American Navy entered the Mediterranean in force in september 1946, it represented a departure from traditional maritime power relationships. The Mediterranean had been a "British Lake" for over one hundred fifty years; thus, the presence of British naval force-in-being was considered routine. Entering the Mediterranean in April 1946 with the battleship Missouri, the symbol of America's victory over Japan (and by implication, of the American possession of the atomic bomb) was a high visibility gesture by the United States. To the world, and especially to the principal nations concerned (Greece, Turkey, Great Britain and the Soviet Union) this U. S. incursion into the Mediterranean with a standing naval force was a radical departure from previous American diplomatic policy, and accordingly, it represented an American involvement in peacetime European 
affairs, an action previously avoided.

This prepositioning of American Naval forces in the Mediterranean during peacetime also represented the global character of American national interests and security concerns. With the realization that American wartime strategy under a PINCHER scenario was entirely dependent upon Middle East oil fields, the need to establish firmly American hegemony in the area was clearly imperative.

The conjunction of the deteriorating geopolitical siutation in the Eastern Mediterranean with the postwar search for a viable mission for the United States Navy was a fortunate circumstance for naval advocates--notwithstanding, the leadership of James Forrestal. In 1945 and 1946, the U. S. Navy was fighting for its very survival. Its apparent obsolescence in the atomic world was the crucial point upon which its continuance pivoted. The Middle East, Turkish Straits and Greek crises of 1946 provided Naval leaders with a stage upon which to prove their merit.

Retrospective assassments of the Missouri's visit, its perceived significance, and its net effects illustrate that a flexible, mobile naval force is as effective in preventing conflict as it is in fighting battles. The threat to Turkey in 1946 came from an impressive Red Army massed on its borders not from naval guns aimed at Istanbul. The USS Missouri was not intended to alter the local balance 
of power but to convince the Soviet Union that Turkish autonomy was in the best interests of the United States and would be guaranteed by the presence of American Naval vessels along the Turkish littoral.

It would be difficult to exaggerate the significance of the permanent commitment of American Naval forces to the Mediterranean arena. By its naval presence the United States was signalling the Soviet Union and the rest of Europe that it would be continuously and directly involved in the conduct of European affairs. Furthermore, the dispatch of these naval vessels must be viewed as the first major military action of the Cold War, an action taken long before the issuance of the Truman Doctrine, the Berlin Airlift, and the formation of NATO. 152 Irrespective of the regional tensions which may have acted as stimuli for the creation of the Sixth Fleet, there was behind it a global purpose: the preservation of American prestige worldwide and the tangible support for one of the basic premises of United States diplomacy--the inviolability of the Open Door. The cruises of U. S. Navy warships in the Mediterranean Sea during this crucial period were, therefore, official, nonverbal but eloquent reminders of the global reach of American power.

152 The Iranian Crisis occurred prior to the voyage of the USS Missouri; however, since military forces were not introduced into Iran to defuse the crisis, the statement that the Missouri's voyage and that of the Roosevelt were the first major military actions of the cold War stands. 


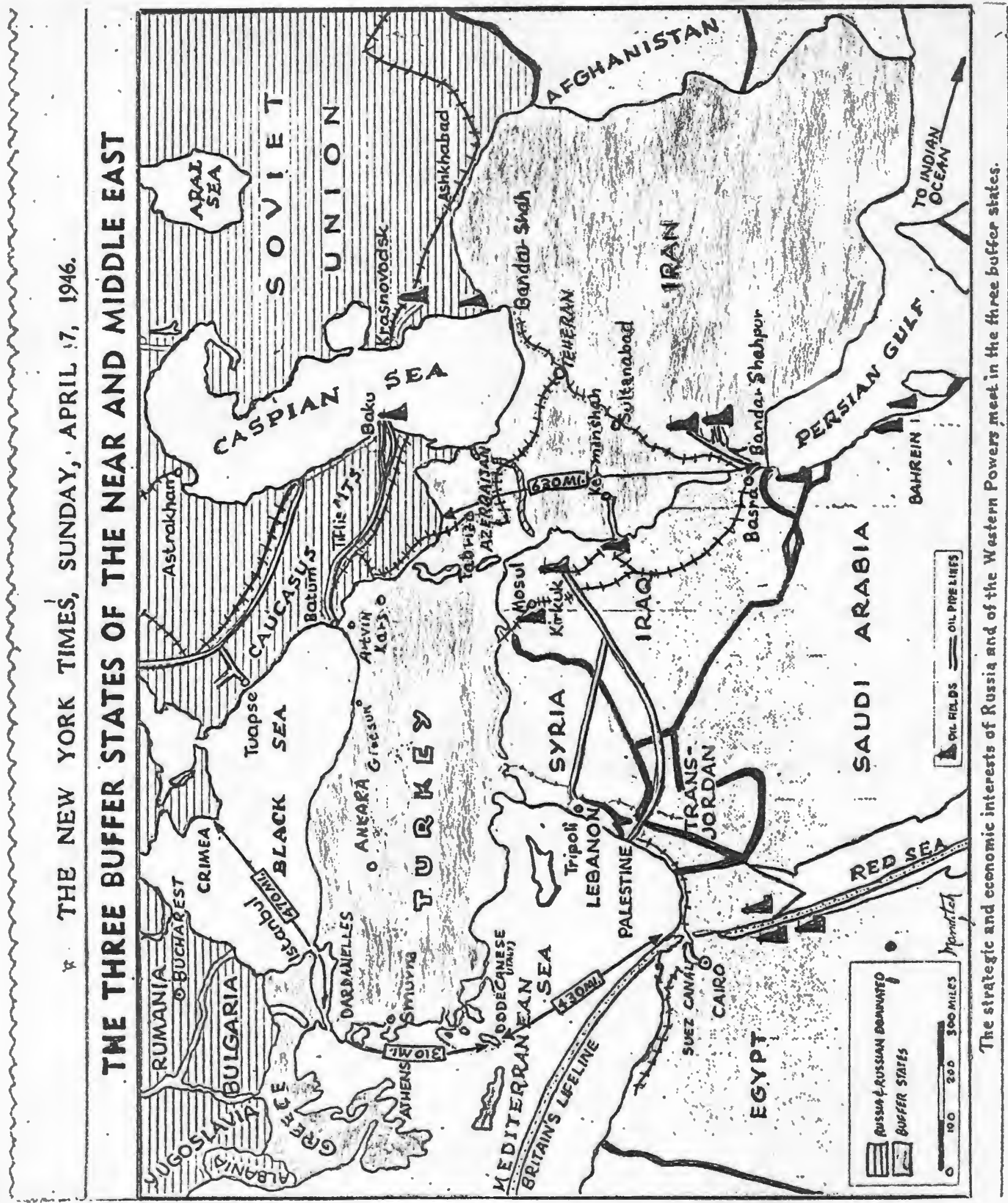




\section{APPENDIX B}

The Chain of Command for U. S. Naval Forces, Mediterranean

\section{Prior to the Establishment of the \\ U. S. Sixth Fleet}

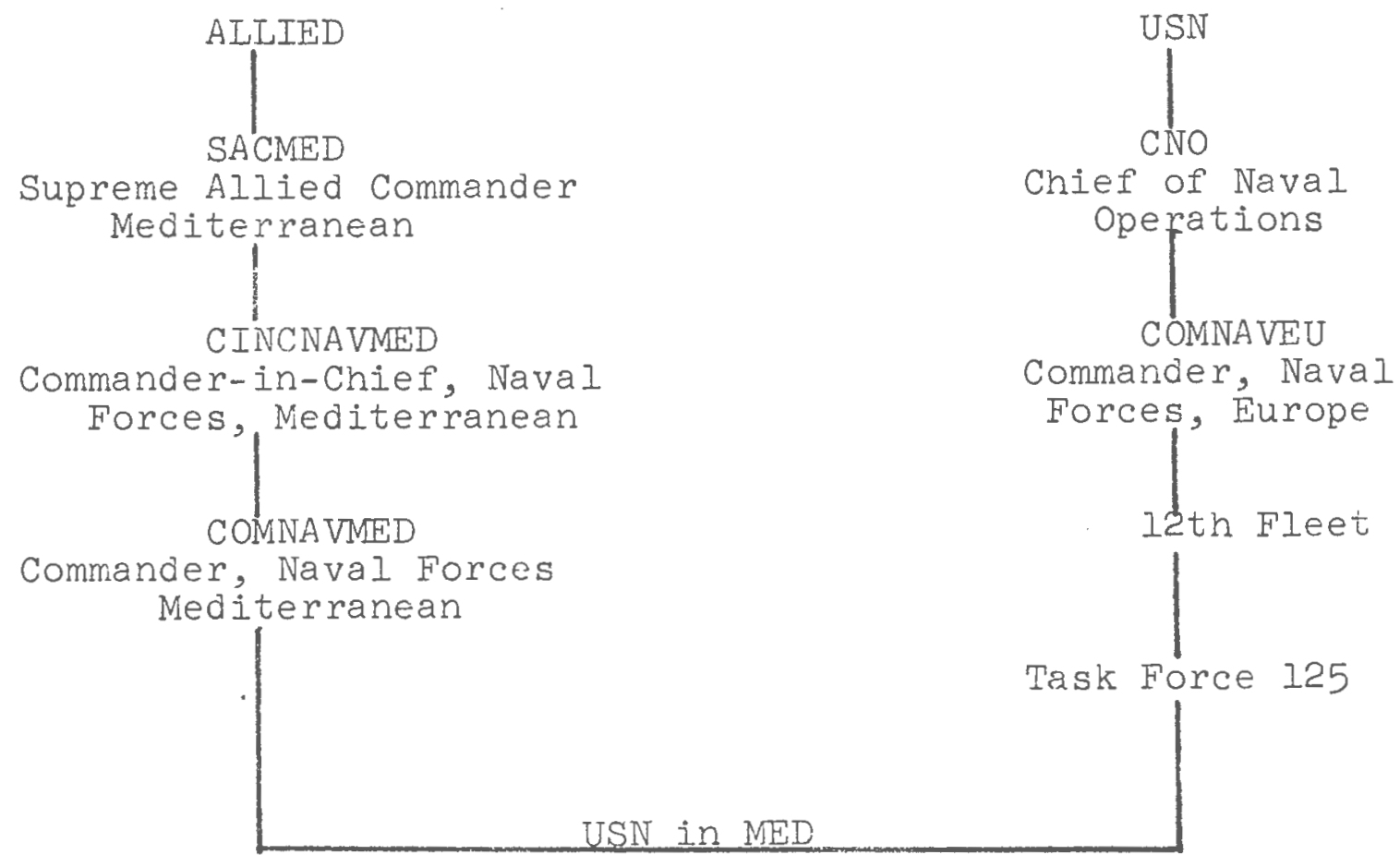




\section{BIBLIOGRAPHY}

Acheson, Dean. Present at the Creation. New York: W. W. Norton \& Co., Inc., 1969.

Albion, Robert G. The Makers of Naval Policy, 1798-1947. Rowena Reed, editor. Annapolis: U. S. Naval Institute Press, 1980.

Albion, Robert G. and Robert H. Connery. Forrestal and the Navy. New York: Columbia University Press, 1962 .

Baram, Philip J. The Department of state in the Middle East, 1919-1945. Philadelphia: The University of Pennsylvania Press, 1973.

Beers, Henry P. "U. S. Naval Department in Turkish Waters, 1919-1924." Administrative Reference Service Report No. 2. Washington: Office of Records Administration, Administrative Office, Department of the Navy, June 1943.

Butler, William. The Soviet Union and the Law of the Sea. Baltomore: The Johns Hopkins University Press, 1971 .

Byrnes, James F. All in One Lifetime. New York: Harper \& Row, 1958.

- Speaking Frankly. New York: Harper \& Row, 1947.

Cave, Guy, Captain, USN. The Build-up of U. S. Naval Forces in the Mediterranean as an Instrument of Cold War Policy. Washington: National War College, 1975 .

Davis, Vincent. Postwar Defense Policy and the U. S. Navy, 1943-1946. Chapel Hill: University of North Carolina Press, 1966.

Donovan, Robert J. Conflict and Crisis: The Presidency of Harry S. Truman, 1945-1948. New York: W. W. Norton \& Co., Inc., 1977 .

Guttridge, Leonard F. and Jay D. Smith. The Commodores. New York: Harper \& Row, 1969. 
Harris, George S. Troubled Alliance: Turkish-American Problems in Historical perspectives, 1945-1971. Washington: American Institute for Foreign Policy Research, 1972 .

Howard, Harry. The Problems of the Turkish Straits. U. S. Department of State Publication \#2752. Washington: Government Printing Office, 1959.

Kuniholm, Bruce. The Origins of the Cold War in the Near East. Princeton: Princeton University Press, 1980.

LaFeber, Walter. America, Russia, and the Cold War, 19451975. New York: John Wiley \& Son, Inc., 1976.

Leahy, William D. I Was There. New York: Whittlesey House, 1950.

Lewis, Jesse W. Jr. The Strategic Balance in the Mediterranean. Washington: American Enterprise Institute for Public Research, 1976.

Luttwak, Edward N. The Political Uses of Sea Power. Studies in International Affairs Number 23. Washington: The Washington Center of Foreign Policy Research of the Johns Hopkins University School of Advanced International Studies, 1974.

Mills, Walter, editor. The Forrestal Diaries. New York: The Viking Press, 1951.

McNeill, William H. America, Britain, and Russia: Their Co-operation and Conflict, 1941-1946. 'New York: Johnson Reprint Corporation, 1970.

Rogow, Arnold A. James Forrestal: A Study of Personality, Politics, and Policy. New York: The MacMilian Co., 1963 .

Articles and Dissertations

Alvarez, David J. "The U. S. and Turkey 1945-1960: The Bureaucratic Determinants of Cold War Diplomacy." Ph.D. Dissertation, University of Connecticut, 1975.

Blair, Leon B. "Mediterranean Geopolitics." United States Institute Proceedings (February 1951): 134

Brodie, Bernard. "New Tactics in Naval Warfare." Foreign Affairs (January 1946): 210. 
Carney, Robert B. "The Principles of Sea Power." United States Naval Institute Proceedings (August 1953): 317.

Crowe, Fletcher, III. "The Soviet Union and the Turkish Straits 1933-1945." Ph.D. Dissertation, Florida State University, 1973.

Eller, Ernest M. "Sea Power and Peace." United States Naval Institute Proceedings (October 1947): 1161.

Fields, Harvey J. "Pawns of Empires: A Study of U. S. Middle East Policies, 1945-1953." Ph.D. Dissertation, Rutgers University, 1975.

Hourihan, William J. "The Best Ambassador: Rear Admiral Cotton and the Cruise of the European Squadron, 1903." Naval War College Review (June-July 1979): 63.

"Marlinspike Diplomacy: The Navy in the Mediterranean, 1904." United States Naval Institute Proceedings (January 1979): 42 .

"Our Naval 'Big Stick' Abroad: A Warning Against Aggression." U. S. News, 13 September.1946, p. 22.

Pratt, Fletcher. "World War II and the Changing Conception of Sea Power." United States Naval Institute Proceedings (January 1946): 1.

Sulzberger, C. I. "Steady Soviet Pressure Expected in the Near East." New York Times, 17 April 1946, p. 6.

"US Displays Force in Europe to Check Russian Expansion." World Report, 5 september 1946, p. 5.

"U. S. Fleet in the Middle East." Life, 26 May 1947, p. 38.

Xydis, Stephen G. "The American Naval Visits to Greece and the Eastern Mediterranean in 1946: Their Impact on Soviet-American Relations." Ph.D. Dissertation, Columbia University, 1956.

Newspapers and Periodicals

New York Herald Tribune, September-October 1946.

New York Times, February-November 1946.

United States Naval Institute Proceedings, Global News Section. 
Vital Speeches, 1946.

World Reports, 1946

\section{Official Sources}

Department of State Bulletin, XIV, 3 February 1946

U. S. Congress, H. of Rep. Composition of the Postwar Navy. Washington: Government Printing Office, 1945.

- H. of Rep. Composition of the Postwar Navy. Washington: Government Printing Office, 1946.

- Senate. Navy Department Appropriation Bill for 1946. Washington: Government Printing Office, 1945.

- Senate. Hearings Before the Senate Committee on Naval Affairs, H.R. 4421. Washington: Government Printing Office, 1946.

- Senate. Hearings on Unification, Armed Services Committee, 1947. Washington: Government Printing Office, 1947.

- Sundry Legislation Affecting the Naval Establishment 1945. Washington: Government Printing office, 1945 .

U. S. Department of State. Papers Relating to the Foreign Relations of the United States, 1946, VII. Washington: Government Printing Office, 1947.

Unpublished Sources

Admiral H. Kent Hewitt Oral History Transcript. Special Collection Section, U. S. Naval Academy Library, Annapolis, Maryland.

James V. Forrestal Papers. Mudd Library, Princeton University, Princeton, New Jersey. Collection includes much which was excluded from Walter Mills, The Forrestal Diaries, for security reasons. Personal papers are closed. (Special permission is required from the Forrestal Estate.)

Pricolo, Dennis M. "Naval Presence and Cold War Foreign 
Policy: A Study of the Decision to Station the 6th Fleet in the Mediterranean, 1945-1958." Trident Report Number 95. Annapolis: U. S. Naval Academy, 1978. Trident studies, although unclassified, are very difficult to acquire. Therefore, it included under the unpublished sources.

Operational Archives, Naval History Division. OP-30 Records on War Plans, Al6-3(5). War Plans, 1946.

Operational Archives, U. S. Naval Academy Library, Annapolis,

- Maryland. Chief of Naval Operations' Ships' Card File.

- Letters and Dispatches Relating to - the Mediterranean Voyage of the Missouri. - Navy Organization Manual 1946. 